\title{
AIRBORNE ELECTROMAGNETIC AND MAGNETIC SURVEY, GOLDSTREAM CREEK WATERSHED, INTERIOR ALASKA
}

Emond, A.M., Daanen, R.P., Graham, G.R.C., Walter Anthony, K., Liljedahl, A.K., Minsley, B.J., Barnes, D.L., Romanovsky, V.E., and CGG Canada Services Ltd.

Geophysical Report 2016-5

September 2018

STATE OF ALASKA

DEPARTMENT OF NATURAL RESOURCES

DIVISION OF GEOLOGICAL \& GEOPHYSICAL SURVEYS

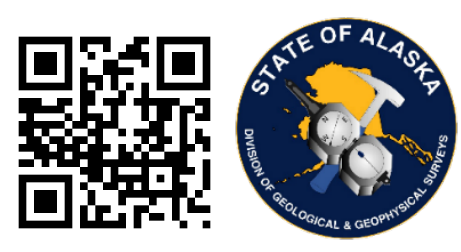




\section{STATE OF ALASKA \\ Bill Walker, Governor}

\section{DEPARTMENT OF NATURAL RESOURCES}

Andrew T. Mack, Commissioner

\section{DIVISION OF GEOLOGICAL \& GEOPHYSICAL SURVEYS}

Steve Masterman, State Geologist \& Director

Publications produced by the Division of Geological \& Geophysical Surveys are available to download from the DGGS website (dggs.alaska.gov). Publications on hard-copy or digital media can be examined or purchased in the Fairbanks office:

\section{Alaska Division of Geological \& Geophysical Surveys (DGGS)}

3354 College Road | Fairbanks, Alaska 99709-3707

Phone: 907.451.5010 | Fax 907.451.5050

dggspubs@alaska.gov |dggs.alaska.gov

\section{DGGS publications are also available at:}

Alaska State Library, Historical

Collections \& Talking Book Center

395 Whittier Street

Juneau, Alaska 99801

Alaska Resource Library and

Information Services (ARLIS)

3150 C Street, Suite 100

Anchorage, Alaska 99503

\section{Suggested citation:}

Emond, A.M., Daanen, R.P., Graham, G.R.C., Walter Anthony, K., Liljedahl, A.K., Minsley, B.J., Barnes, D.L., Romanovsky, V.E., and CGG Canada Services Ltd., 2018, Airborne electromagnetic and magnetic survey, Goldstream Creek watershed, interior Alaska: Alaska Division of Geological \& Geophysical Surveys Geophysical Report 2016-5, 14 p. http://doi.org/10.14509/29681
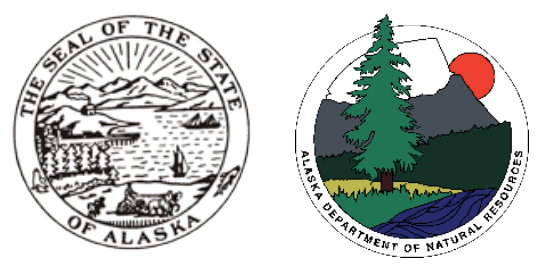


\section{AIRBORNE ELECROMAGNETIC AND MAGNETIC SURVEY, GOLDSTREAM CREEK WATERSHED, INTERIOR ALASKA}

Abraham M. Emond ${ }^{1}$, Ronnie P. Daanen ${ }^{1}$, Gina R.C. Graham ${ }^{1}$, Katey Walter Anthony ${ }^{2}$, Anna K. Liljedahl ${ }^{2}$, Burke J. Minsley ${ }^{3}$, David L. Barnes ${ }^{4}$, Vladimir E. Romanovsky ${ }^{5}$, and CGG Canada

Services Ltd.

\section{ABSTRACT}

A National Science Foundation grant to study Arctic hydrology-permafrost-methane systems was awarded to the University of Alaska Fairbanks (UAF), Institute of Northern Engineering, Water and Environmental Research Center with the Alaska Division of Geological \& Geophysical Surveys (DGGS) as a co-investigator. As part of the study, DGGS managed the collection, modelling, and interpretation of airborne electromagnetic and magnetic data over a 258-square-km portion of the Goldstream Creek watershed, interior Alaska. The survey was flown from March $6^{\text {th }}$ to March $17^{\text {th }}, 2016$ by CGG using their RESOLVE airborne geophysical system with a line spacing of either 100 meters $(\mathrm{m})$ or $200 \mathrm{~m}$; additional custom lines were collected over areas of scientific interest. The data were measured from $30 \mathrm{~m}$ above the ground surface using a helicopter-towed sensor platform ("bird") on a 30-m long line.

\section{PURPOSE}

The UAF and DGGS Goldstream Valley Watershed project aims to define processes within the hydrology-permafrost-methane system at the lake to watershed scale, and across seasonal to millennial time scales. Airborne-geophysical datasets were collected to facilitate understanding of surface and subsurface features and processes within Goldstream Valley and surrounding areas of interior Alaska. This sub-arctic region's hydrology-permafrost-methane system contains discontinuous permafrost and thaw lakes and offers a conveniently located and data-rich study area.

\section{SURVEY OVERVIEW DESCRIPTION}

This document provides an overview of the survey and includes text and figures of select primary and derivative products of this survey. A table of digital data packages available for download is provided to assist users in data selection. For reference a catalog of the available maps is presented in reduced resolution. Please consult the metadata, project report, and digital data packages for more information and data.

\footnotetext{
${ }^{1}$ Alaska Division of Geological \& Geophysical Surveys, 3354 College Road, Fairbanks, Alaska 99709-3707

${ }^{2}$ Water and Environmental Research Center (WERC), University of Alaska Fairbanks, P.O. Box 755860, Fairbanks, Alaska 99775

${ }^{3}$ Geology, Geophysics, and Geochemistry Science Center, U.S. Geological Survey, W 6 ${ }^{\text {th }}$ Ave., Kipling St., Lakewood, CO 80225

${ }^{4}$ College of Engineering and Mines, University of Alaska Fairbanks, P.O. Box 755900, Fairbanks, Alaska 99775

${ }^{5}$ Geophysical Institute, University of Alaska Fairbanks, 903 Koyukuk Drive, Fairbanks, Alaska 99775
} 
Airborne electromagnetic and magnetic survey,

Goldstream Creek watershed, interior Alaska

\section{AVAILABLE DATA}

\begin{tabular}{|c|c|c|}
\hline Data Type & Provider & Description \\
\hline ascii_data & contractor & ASCII format line data, other ASCII data \\
\hline databases_geosoft & contractor & $\begin{array}{l}\text { Geosoft format database of final line data, other Geosoft format } \\
\text { databases }\end{array}$ \\
\hline documents & contractor & $\begin{array}{l}\text { Project and field reports, survey background information, gridded } \\
\text { data explanations, other documentation }\end{array}$ \\
\hline grids_ermapper & DGGS & Geographically registered gridded data, ER Mapper ERS format \\
\hline grids_geosoft & DGGS & $\begin{array}{l}\text { Geosoft-format binary grids, these grids can be viewed in ESRI } \\
\text { ArcMap using a free plugin from Geosoft }\end{array}$ \\
\hline images_registered & DGGS & GeoTiff format images of all gridded data \\
\hline $\mathrm{kmz}$ & DGGS & $\begin{array}{l}\mathrm{kml} \text { language } \mathrm{kmz} \text { archive files of several project data types } \\
\text { including resistivity model depth slices }\end{array}$ \\
\hline maps_pdf_format & contractor & Printable maps in pdf format \\
\hline maps_prn_format & contractor & Printable maps in HPGL/G printer file format with extension .prn \\
\hline outreach_data & DGGS & $\begin{array}{l}\text { Data for the general public that requires no specialized software to } \\
\text { view. Intended for educational use. Includes resistivity models }\end{array}$ \\
\hline vector_data & DGGS & $\begin{array}{l}\text { Line path, data contours, and survey boundary in ESRI shape file } \\
\text { (SHP) format }\end{array}$ \\
\hline photos_flightpath & DGGS & $\begin{array}{l}\text { Survey flight path downward facing photos with GPS location in exif } \\
\text { data }\end{array}$ \\
\hline resistivity_models & DGGS & $\begin{array}{l}\text { ACSII CSV format resistivity models in project coordinates with data } \\
\text { field guides, figures and supporting documentation in ASCII text, } \\
\text { PDF, KML, and/or other formats }\end{array}$ \\
\hline video_flightpath & contractor & Survey flight path downward facing video \\
\hline
\end{tabular}


Airborne electromagnetic and magnetic survey,

\section{ACKNOWLEDGMENTS}

The Goldstream Valley Watershed project is funded by the National Science Foundation, Office of Polar Programs, Arctic System Science Program, award \#1500931.

\section{REFERENCES}

Ball, L.B., Smith, B.D., Minsley, B.J., Abraham, J.D., Voss, C.I., Astley, B.N., Deszcz-Pan, Maria, and Cannia, J.C., 2011, Airborne electromagnetic and magnetic geophysical survey data of the Yukon Flats and Fort Wainwright areas, central Alaska, June 2010: U.S. Geological Survey Open-File Report 2011-1304, 21 p. https://pubs.usgs.gov/of/2011/1304/

Graham, G.C., Emond, A.M., Daanen, R.P., Minsley, B.J., and CGG, in press, Airborne electromagnetic and magnetic survey, Yukon Crossing to Fox profile, interior Alaska: Alaska Division of Geological \& Geophysical Surveys Geophysical Report 2016-3, 1 DVD. http://doi.org/10.14509/29684

Emond, A.M., Little, L.M., Graham, G.C., Minsley, B.J., and CGG, in press, Airborne electromagnetic and magnetic survey, Yukon Crossing, interior Alaska: Alaska Division of Geological \& Geophysical Surveys Geophysical Report 2016-4. http://doi.org/10.14509/29682

Emond, A.M., Minsley, B.J., Daanen R.P., Graham G.C., and CGG, in press, Airborne electromagnetic and magnetic survey, Western Yukon Flats, interior Alaska: Alaska Division of Geological \& Geophysical Surveys Geophysical Report 2016-2, 1 DVD. http://doi.org/10.14509/29683 


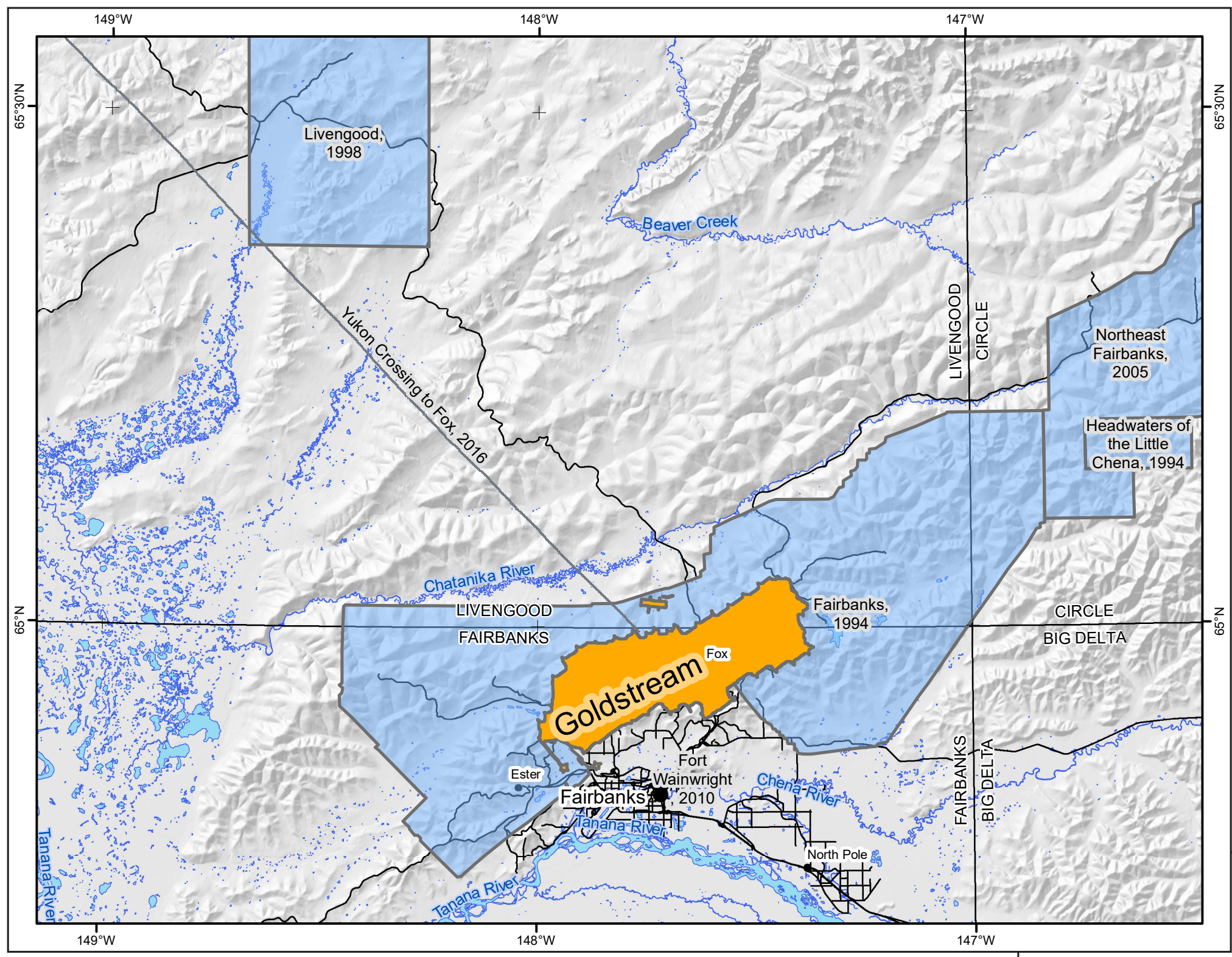

Figure 1. Location map of Goldstream Creek watershed survey area, interior Alaska (inset). Goldstream Creek watershed survey area (orange), nearby and adjacent historical DGGS electromagnetic and magnetic surveys flown at 400-m line spacing (blue), major highways and roads, major rivers, and shaded relief. 


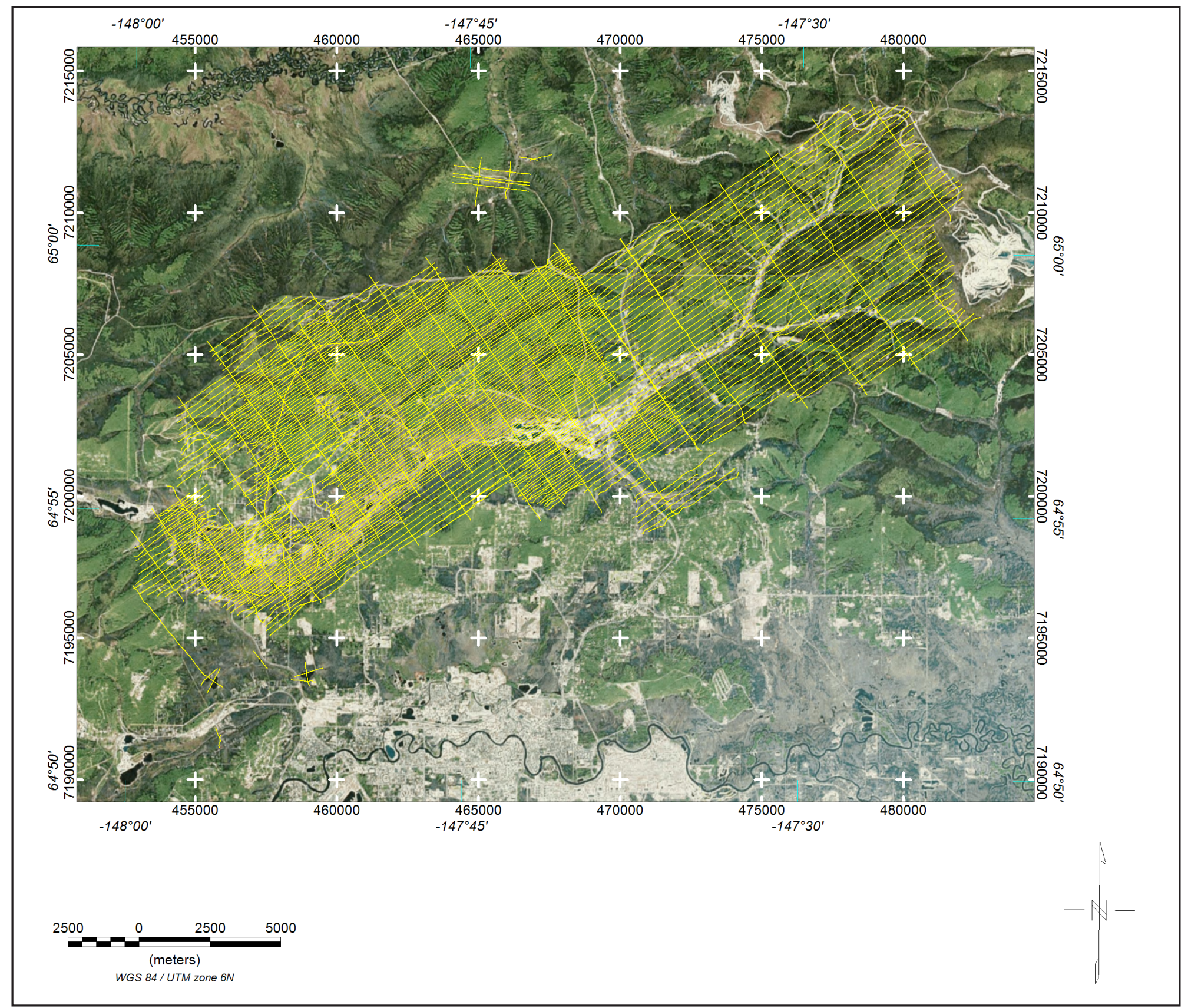

Figure 2. Paths of survey flight lines and wider-spaced perpendicular tie lines with orthophoto of Goldstream Valley. 


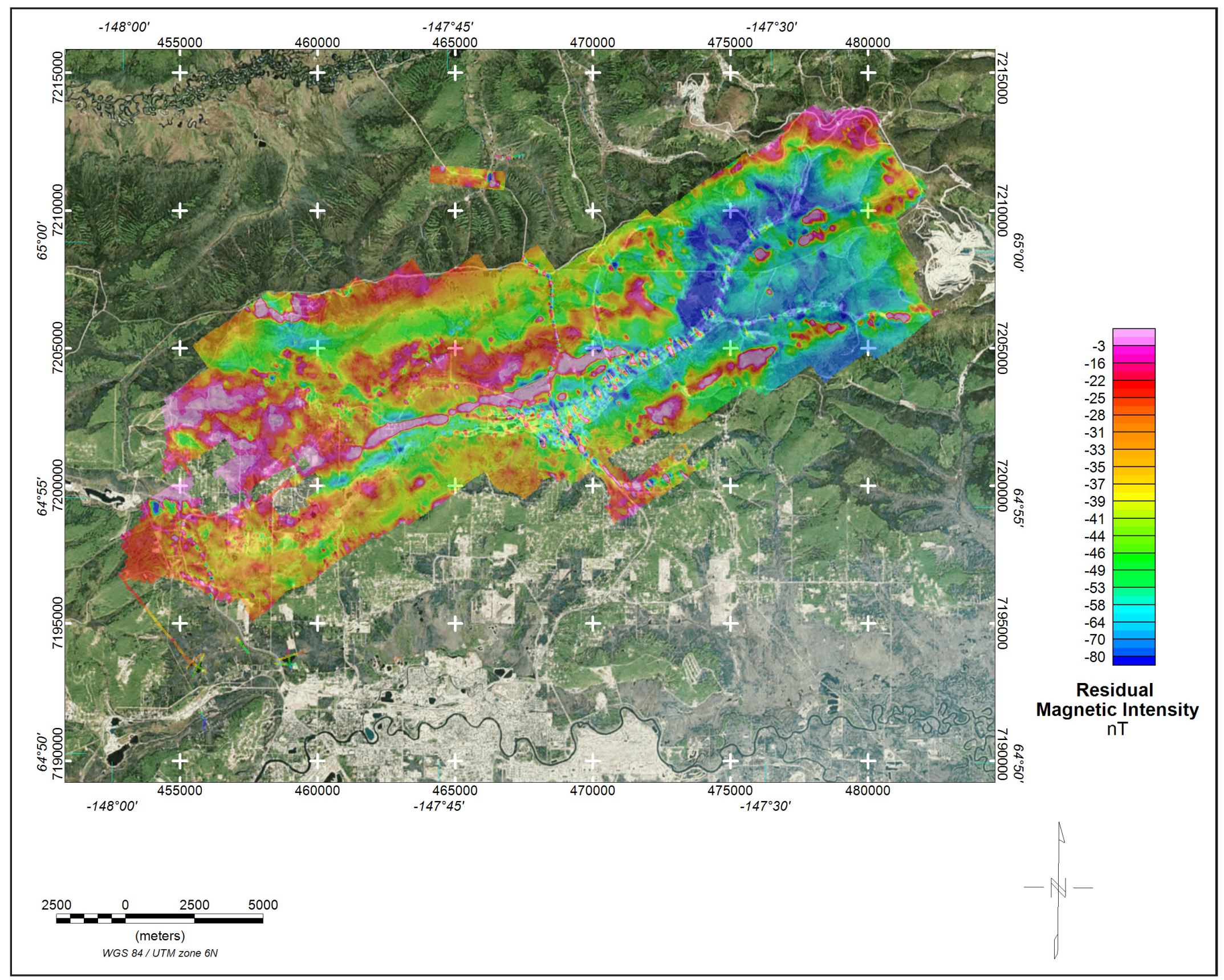

Figure 3. Residual magnetic intensity grid with orthophoto. The magnetic total field data were collected using a Scintrex CS3 cesium sensor at a sampling interval of 0.1 seconds and processed using digitally recorded data from a CGG D1344 base station magnetometer. The magnetic data were: (1) corrected for diurnal variations by subtraction of the base station magnetic data; (2) IGRF corrected (IGRF model 2010, updated for data of flight and altimeter variations); and, (3) leveled using the tie line data. 


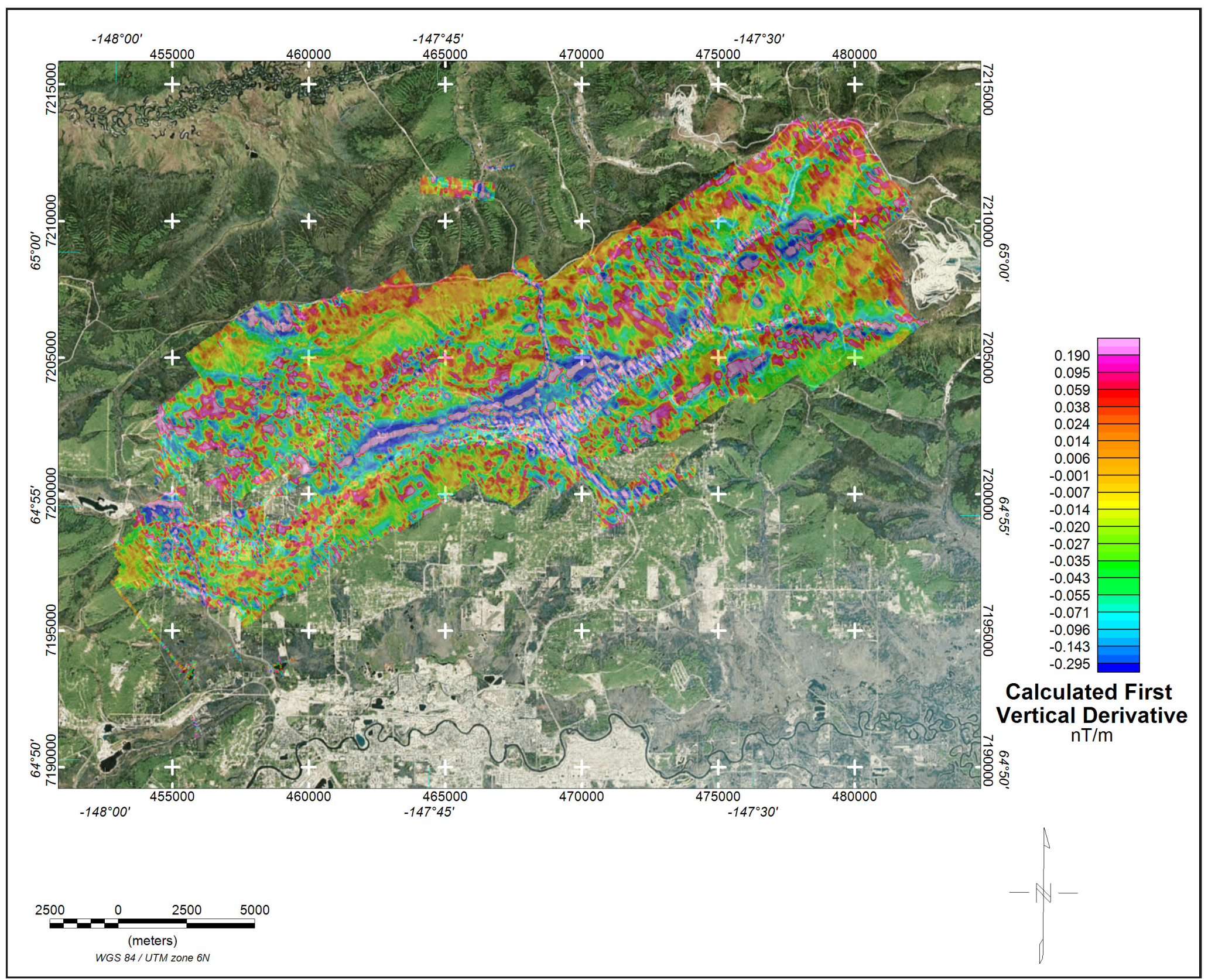

Figure 4. First vertical derivative of the magnetic field grid with orthophoto. The magnetic total field data were collected using a Scintrex CS3 cesium sensor at a sampling interval of 0.1 seconds and processed using digitally recorded data from a CGG D1344 base station magnetometer. The magnetic data were: (1) corrected for diurnal variations by subtraction of the base station magnetic data; (2) IGRF corrected (IGRF model 2010, updated for data of flight and altimeter variations); and, (3) leveled using the tie line data. The first vertical derivative grid was calculated from the processed residual magnetic intensity grid using a Fast-Fourier-Transform (FFT) base frequency domain filtering algorithm. The resulting first vertical derivative grid provides better definition and resolution of near-surface magnetic features and helps to identify weak magnetic features that may not be evident in the residual magnetic data. 


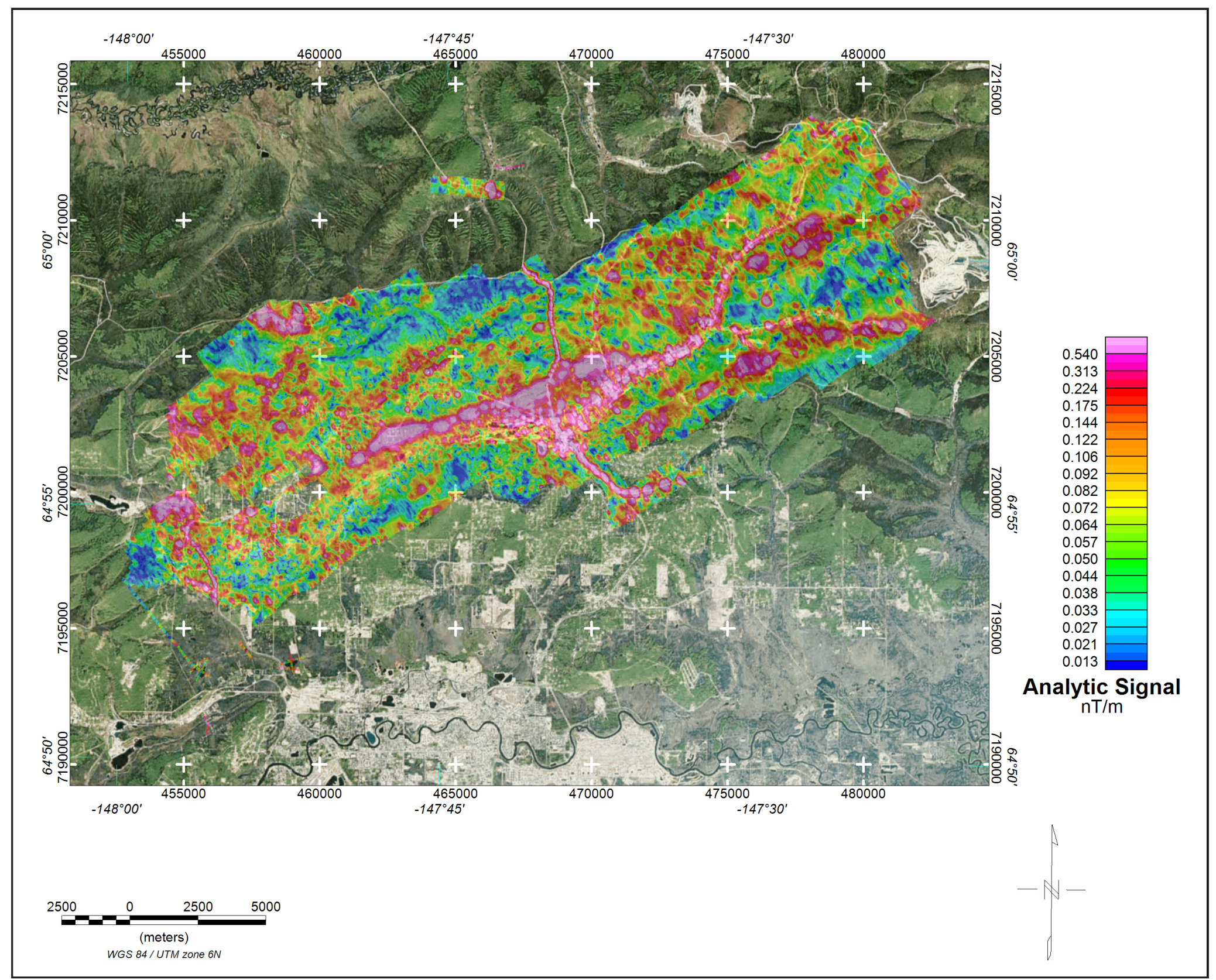

Figure 5. Analytic signal of the magnetic field grid with orthophoto. Analytic signal is the total amplitude of all directions of magnetic gradient calculated from the sum of the squares of the three orthogonal gradients. Mapped highs in the calculated analytic signal of the magnetic parameter locate the anomalous source's edges and corners (such as contacts, fault/shear zones, etc.). Analytic signal enhances the source edges regardless of structural dip and independent of the direction of the induced and/or remanent magnetization. 


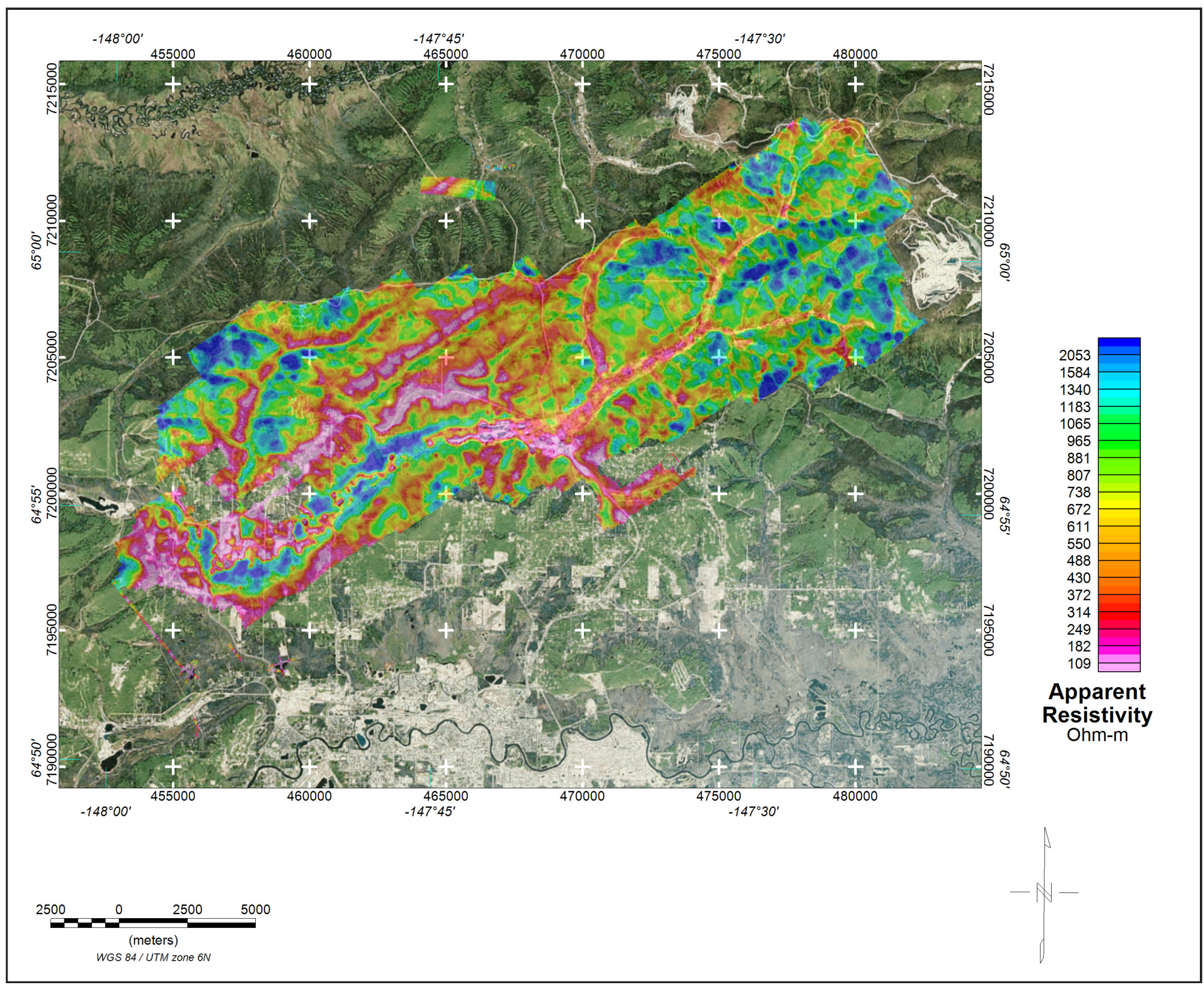

Figure 6. 140,000 hertz (Hz) apparent resistivity grid and orthophoto. The RESOLVE electromagnetic (EM) system operates at six distinct frequencies, and measures the inphase and quadrature components at each frequency. Five coplanar coil pairs operate at 400, 1,800, 8,200, 40,000, and 140,000 Hz (shown), and one coaxial coil pair operates at 3,300 Hz. The EM data were sampled at 0.1 second intervals. The EM system responds to bedrock conductors, conductive overburden, and man-made cultural sources. Apparent resistivity is generated from the inphase and quadrature components for each frequency using the pseudo-layer half-space model. 


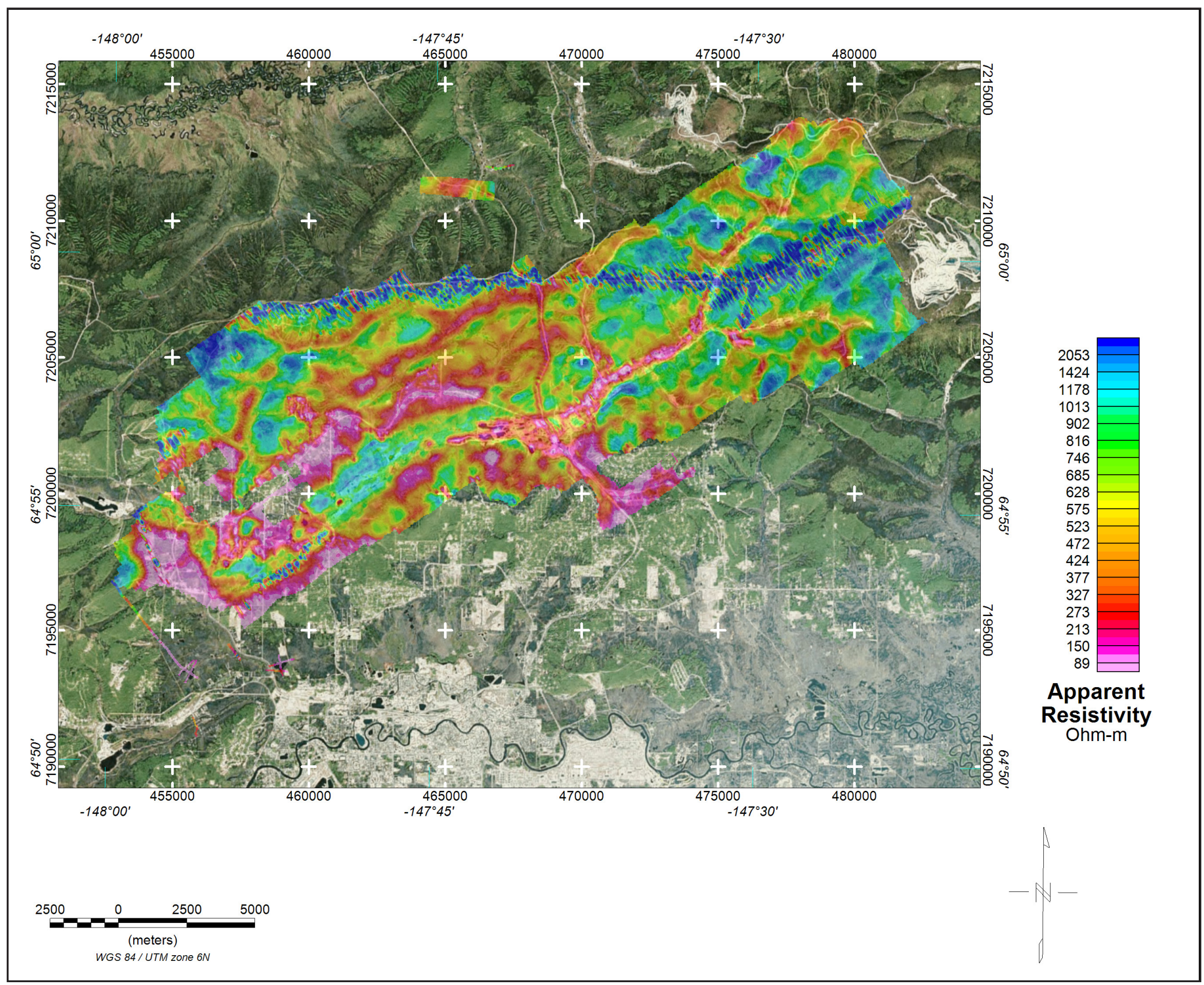

Figure 7. 8,200 Hz apparent resistivity grid and orthophoto. The RESOLVE EM system operates at six distinct frequencies, and measures the inphase and quadrature components at each frequency. Five coplanar coil pairs operate at 400, 1,800, 8,200 (shown), 40,000, and 140,000 Hz, and one coaxial coil pair operates at $3,300 \mathrm{~Hz}$. The EM data were sampled at 0.1 second intervals. The EM system responds to bedrock conductors, conductive overburden, and man-made cultural sources. Apparent resistivity is generated from the inphase and quadrature components for each frequency using the pseudo-layer half-space model. 


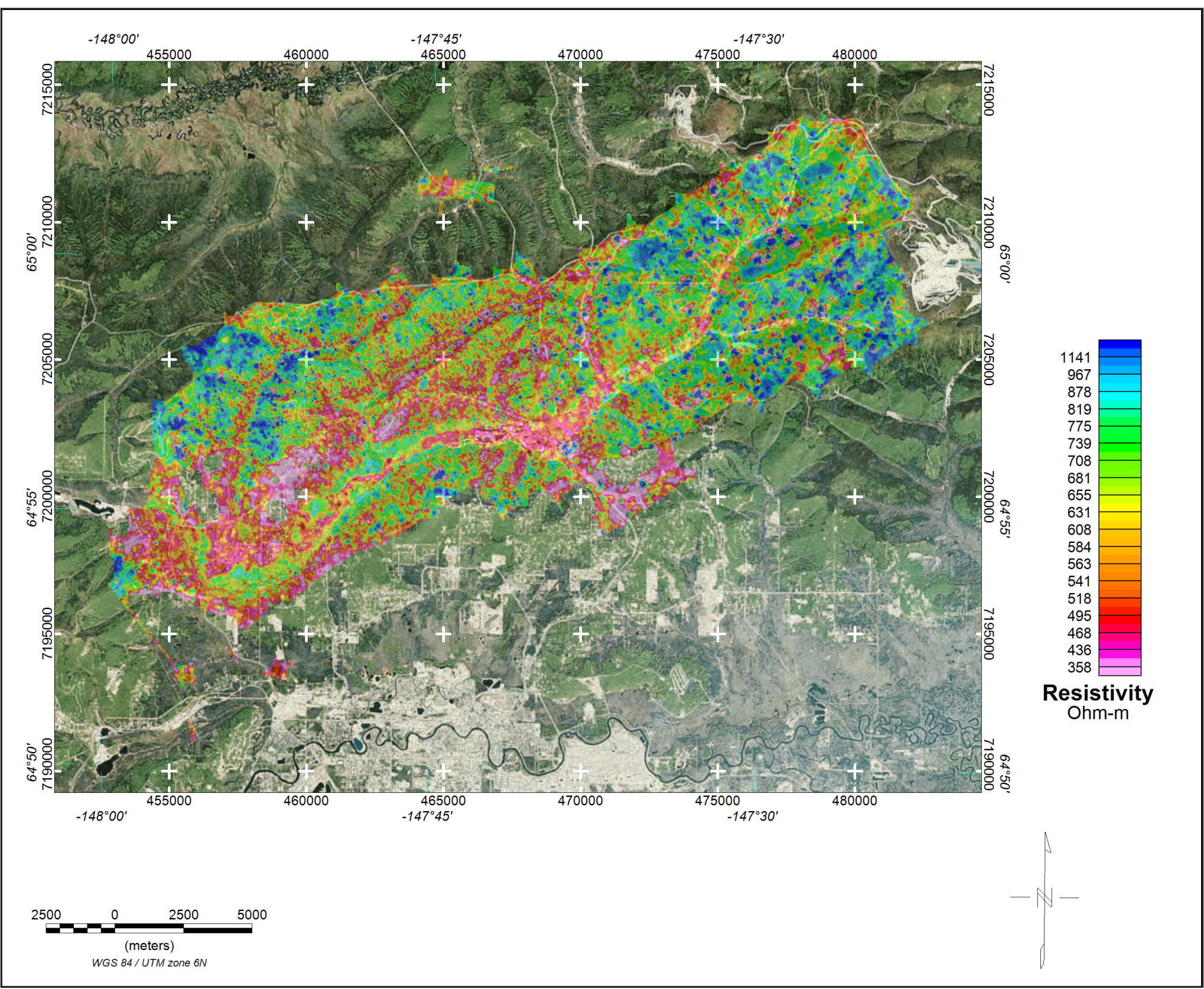

Figure 8. Resistivity model depth-slice grid; at ground surface (first model layer). Resistivity models are created from the recorded electromagnetic data through a process called inversion. Inversion programs create a resistivity model that has a data signature nearly the same as the recorded data. When this occurs the model is said to "fit" the data. This process is non-unique, meaning that many resistivity models could create similar data. The models presented are likely to (but might not) represent the real world distribution of resistivity in the subsurface. The recorded data are influenced by the subsurface on either side of the flight line; therefore, features in the model could be from either side of the flight line. Power lines and other infrastructure can negatively impact the data quality, which could result in missing data and/or cause erroneous models. Resistivity Model "workbench_sci" shown. 


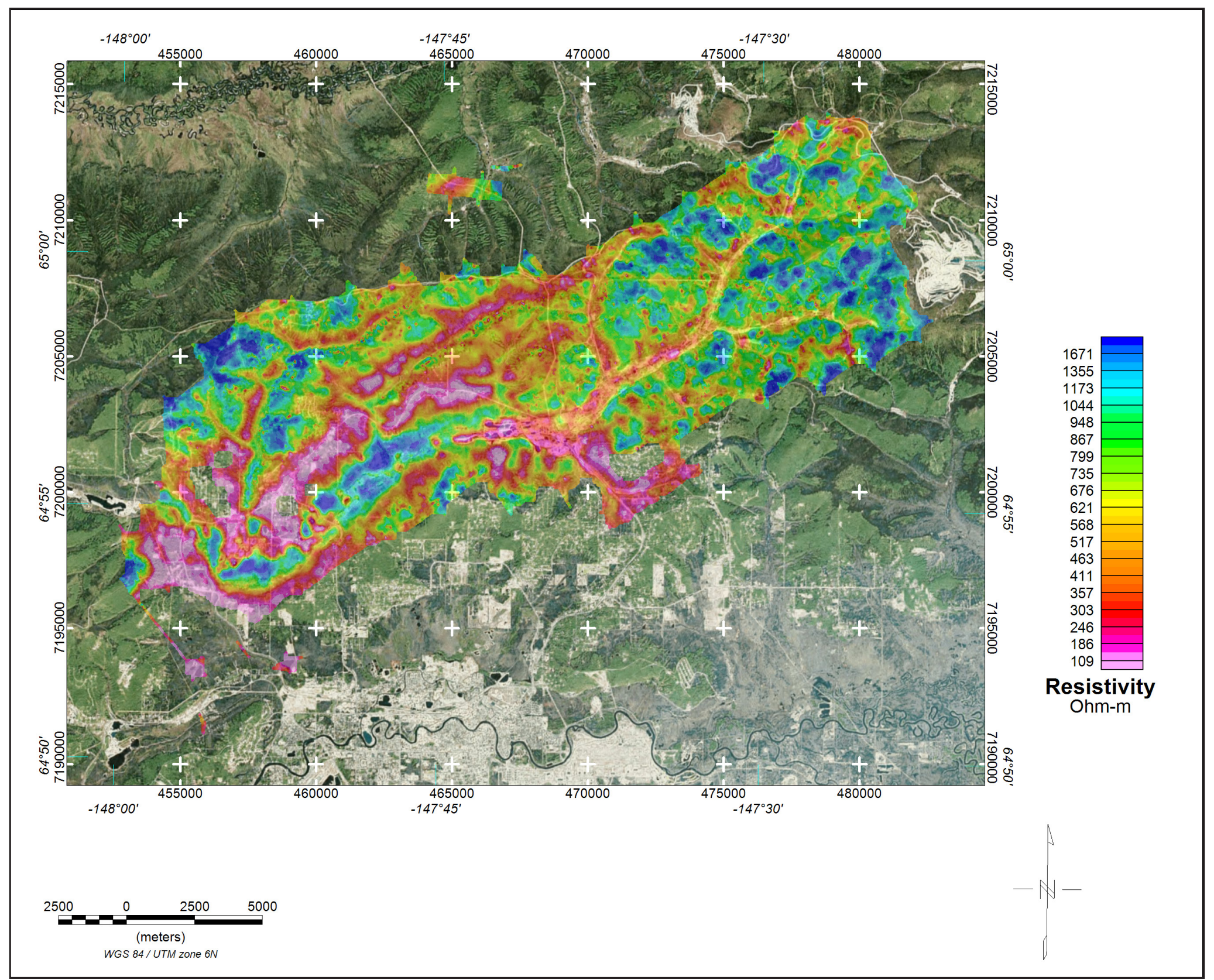

Figure 9. Resistivity model depth-slice grid; 30 meters below ground surface. Resistivity models are created from the recorded electromagnetic data through a process called inversion. Inversion programs create a resistivity model that has a data signature nearly the same as the recorded data. When this occurs the model is said to "fit" the data. This process is non-unique, meaning that many resistivity models could create similar data. The models presented are likely to (but might not) represent the real world distribution of resistivity in the subsurface. The recorded data are influenced by the subsurface on either side of the flight line; therefore, features in the model could be from either side of the flight line. Power lines and other infrastructure can negatively impact the data quality, which could result in missing data and/or cause erroneous models. Resistivity Model "workbench_sci" shown. 


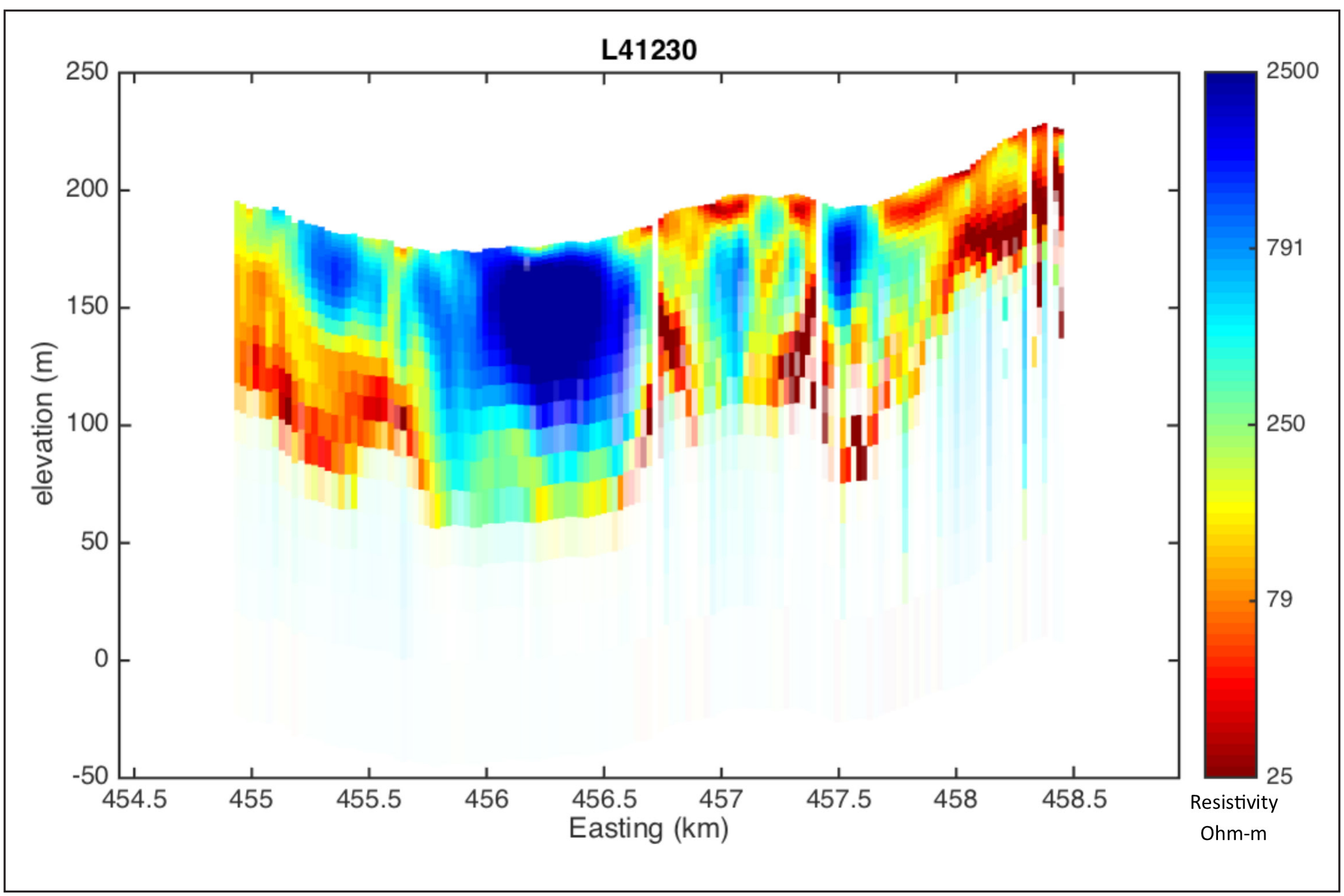

Figure 10. Resistivity model cross section. Resistivity model "em $1 \mathrm{dfm}$ _prelim" from line 41230 shown. Resistivity models are created from the recorded electromagnetic data through a process called inversion. Inversion programs create a resistivity model that has a data signature nearly the same as the recorded data. When this occurs the model is said to "fit" the data. This process is non-unique, meaning that many resistivity models could create similar data. The models presented are likely to (but might not) represent the real world distribution of resistivity in the subsurface. The recorded data are influenced by the subsurface on either side of the flight line; therefore, features in the model could be from either side of the flight line. Power lines and other infrastructure can negatively impact the data quality, which could result in missing data and/or cause erroneous models. 
Table 1. Copies of the following maps are included at the end of this booklet. The low-resolution, page-size maps included in this booklet are intended to be used as a search tool and are not the final product. Large-scale, full-resolution versions of each map are available to download on this publication's citation page: $\underline{\text { http://doi.org/10.14509/29681. }}$

\begin{tabular}{|c|c|}
\hline Map Title & Description \\
\hline _analyticsignal_contours_map & Analytic signal grid (magnetic data), with township, range, and section background \\
\hline _analyticsignal_topo_map & Analytic signal grid (magnetic data), with topography background \\
\hline _calculated1vd_contours_map & Calculated $1^{\text {st }}$ vertical derivative (magnetic data), with township, range, and section background \\
\hline _calculated1vd_topo_map & Calculated $1^{\text {st }}$ vertical derivative (magnetic data), with topography background \\
\hline _res140khz_contours_map & $140000 \mathrm{~Hz}$ coplanar apparent resistivity grid (electromagnetic data), with township, range, and section background \\
\hline _res140khz_topo_map & $140000 \mathrm{~Hz}$ coplanar apparent resistivity grid (electromagnetic data), with topography background \\
\hline _res40khz_contours_map & $40000 \mathrm{~Hz}$ coplanar apparent resistivity grid (electromagnetic data), with township, range, and section background \\
\hline _res40khz_topo_map & $40000 \mathrm{~Hz}$ coplanar apparent resistivity grid (electromagnetic data), with topography background \\
\hline _res8200hz_contours_map & $8200 \mathrm{~Hz}$ coplanar apparent resistivity grid (electromagnetic data), with township, range, and section background \\
\hline _res8200hz_topo_map & $8200 \mathrm{~Hz}$ coplanar apparent resistivity grid (electromagnetic data), with topography background \\
\hline _res3300hz_contours_map & $3300 \mathrm{~Hz}$ coaxial apparent resistivity grid (electromagnetic data), with township, range, and section background \\
\hline _res3300hz_topo_map & $3300 \mathrm{~Hz}$ coaxial apparent resistivity grid (electromagnetic data), with topography background \\
\hline _res1800hz_contours_map & $1800 \mathrm{~Hz}$ coplanar apparent resistivity grid (electromagnetic data), with township, range, and section background \\
\hline _res1800hz_topo_map & $1800 \mathrm{~Hz}$ coplanar apparent resistivity grid (electromagnetic data, with topography background \\
\hline _res400hz_contours_map & $400 \mathrm{~Hz}$ coplanar apparent resistivity grid (electromagnetic data), with township, range, and section background \\
\hline _res400hz_topo_map & $400 \mathrm{~Hz}$ coplanar apparent resistivity grid (electromagnetic data), with topography background \\
\hline _residualmag_contours_map & Residual magnetic intensity grid (magnetic data), with township, range, and section background \\
\hline _residualmag_topo_map & Residual magnetic intensity grid (magnetic data), with topography background \\
\hline
\end{tabular}




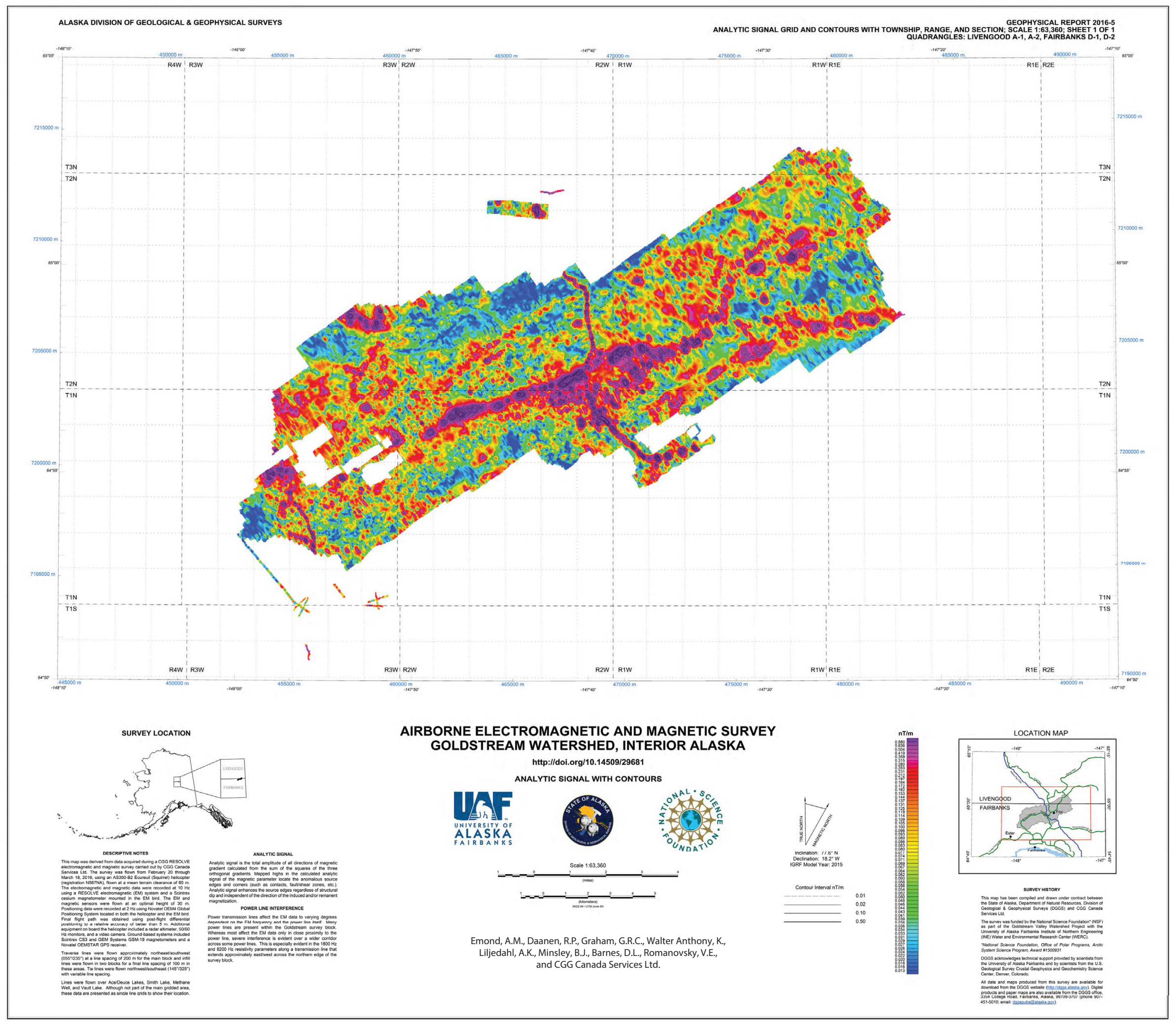




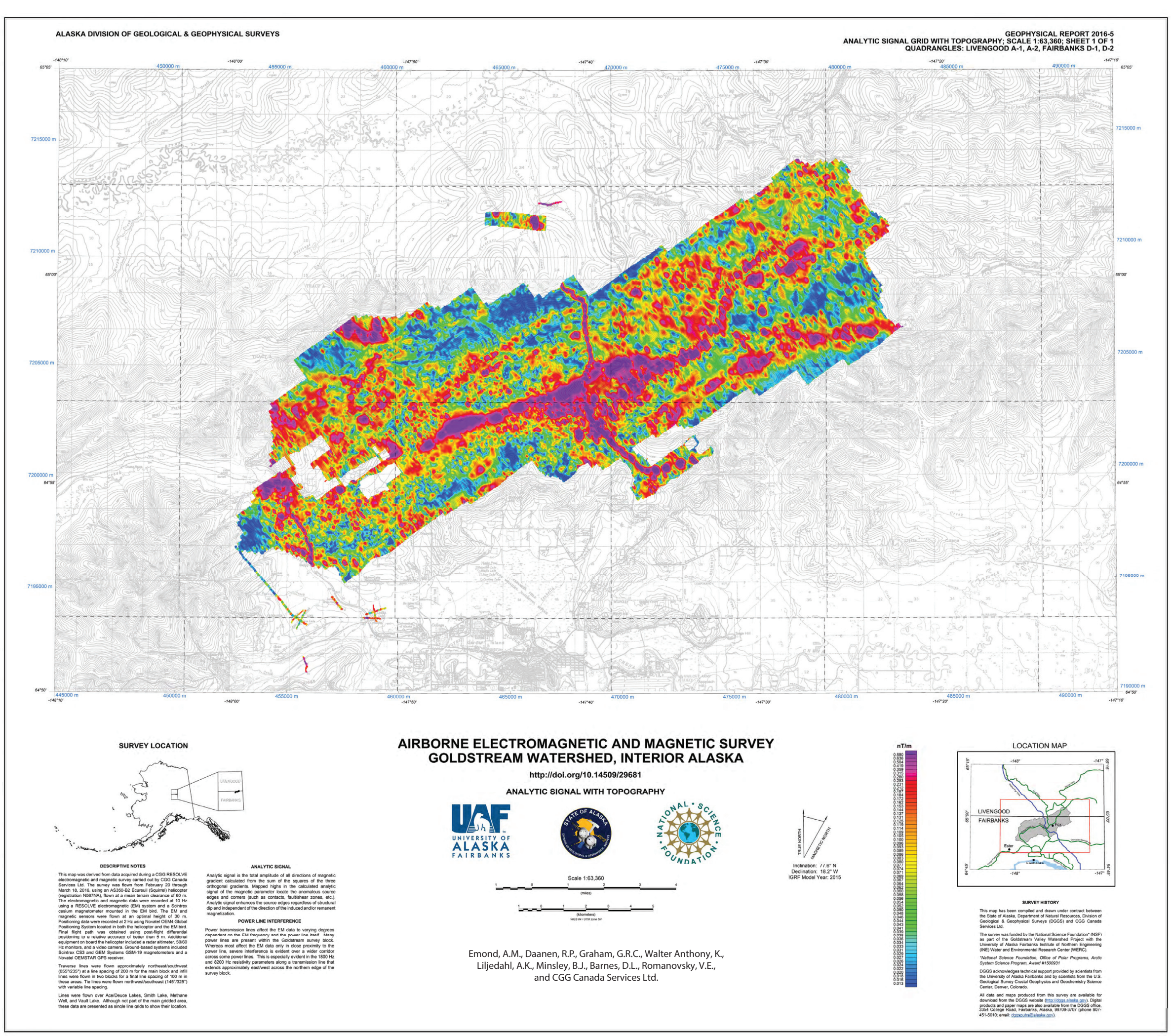




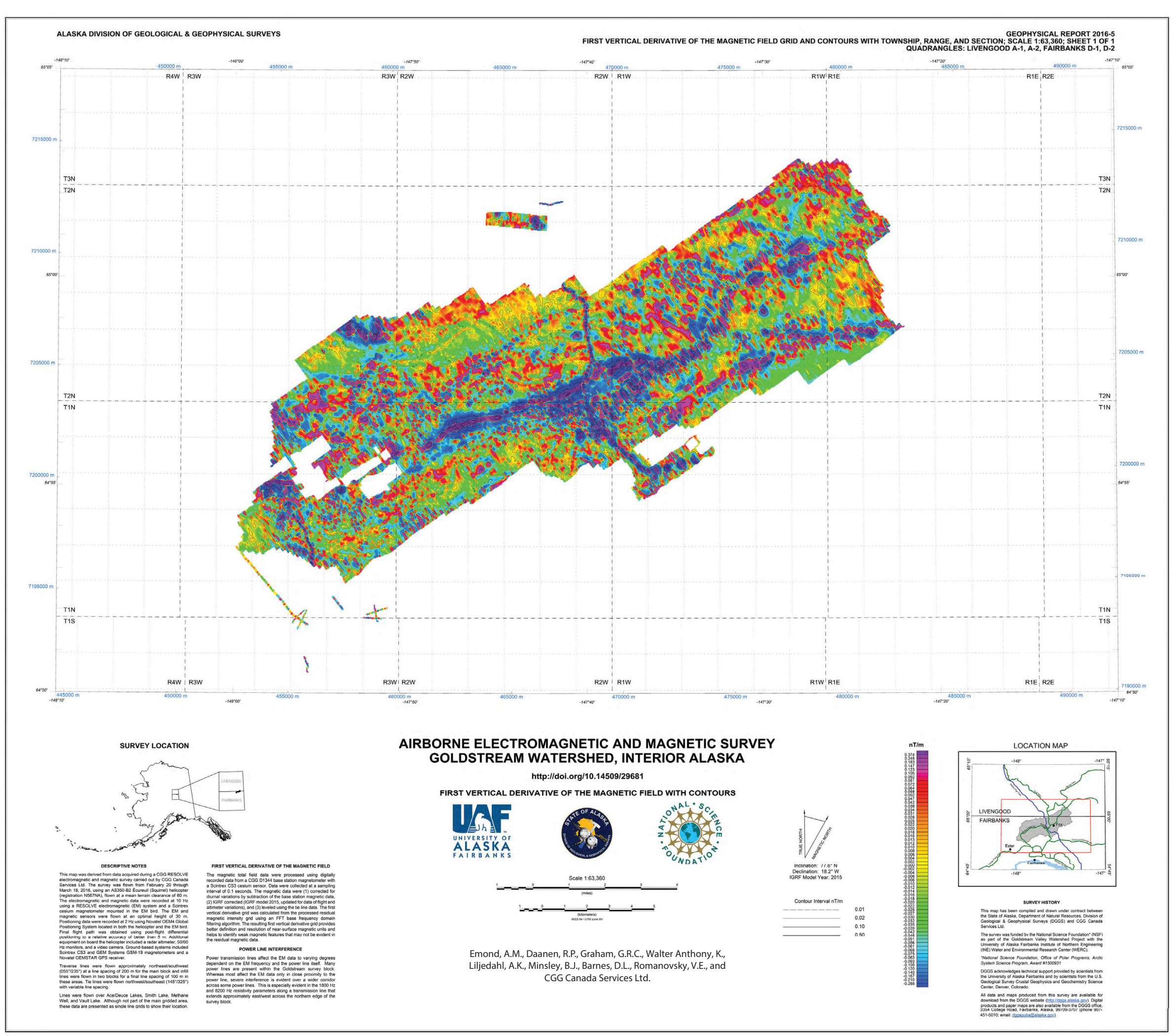




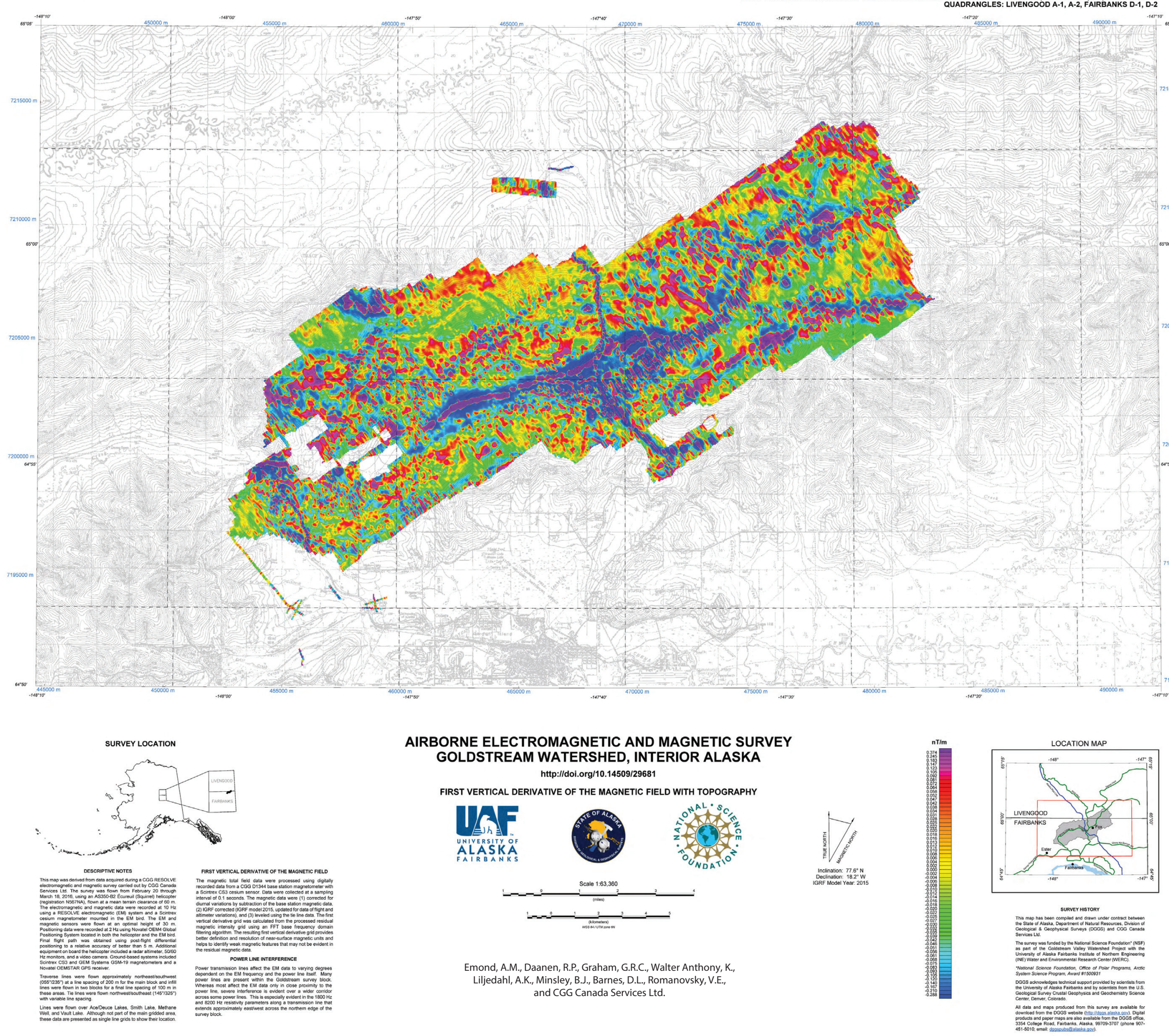




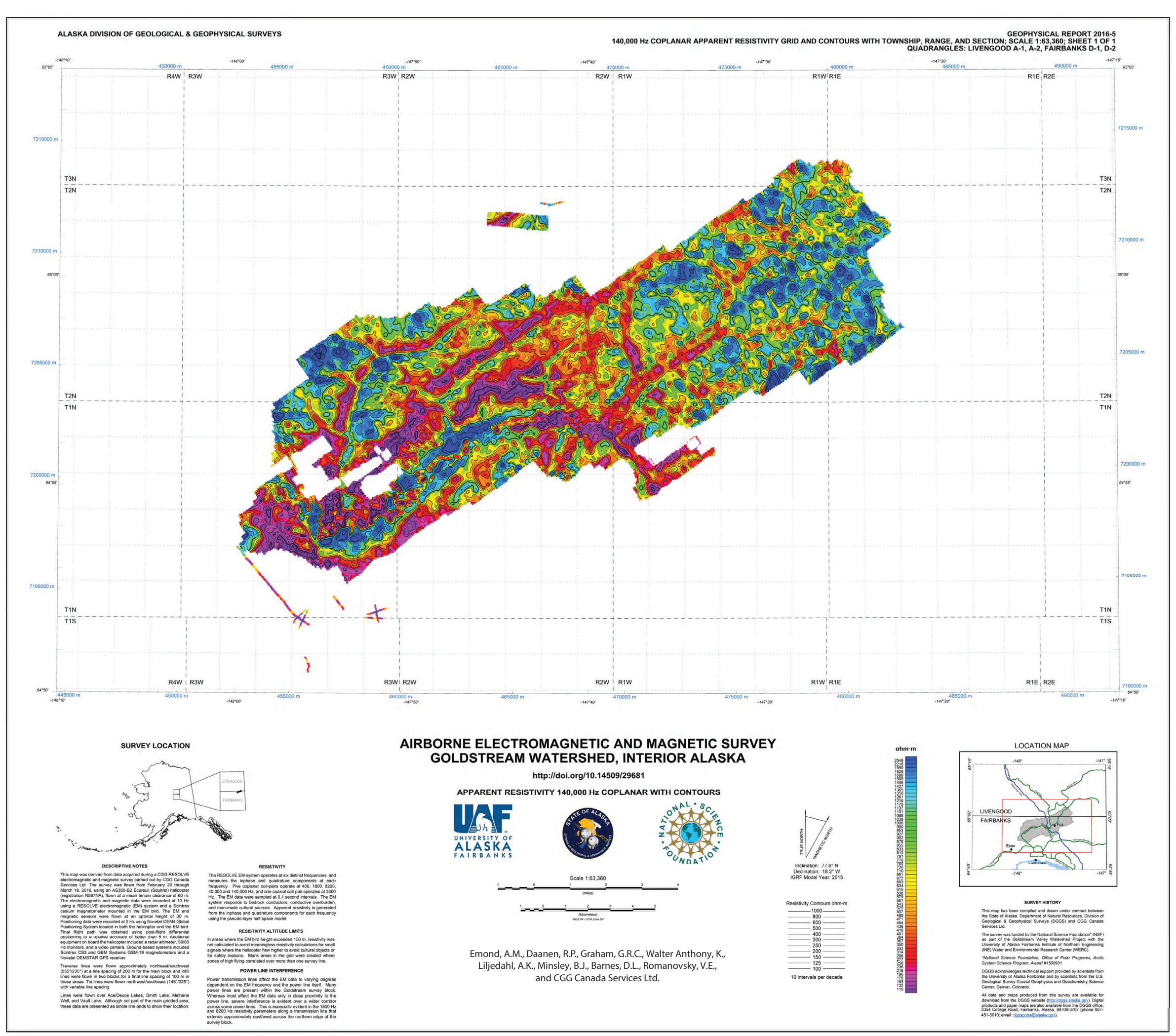




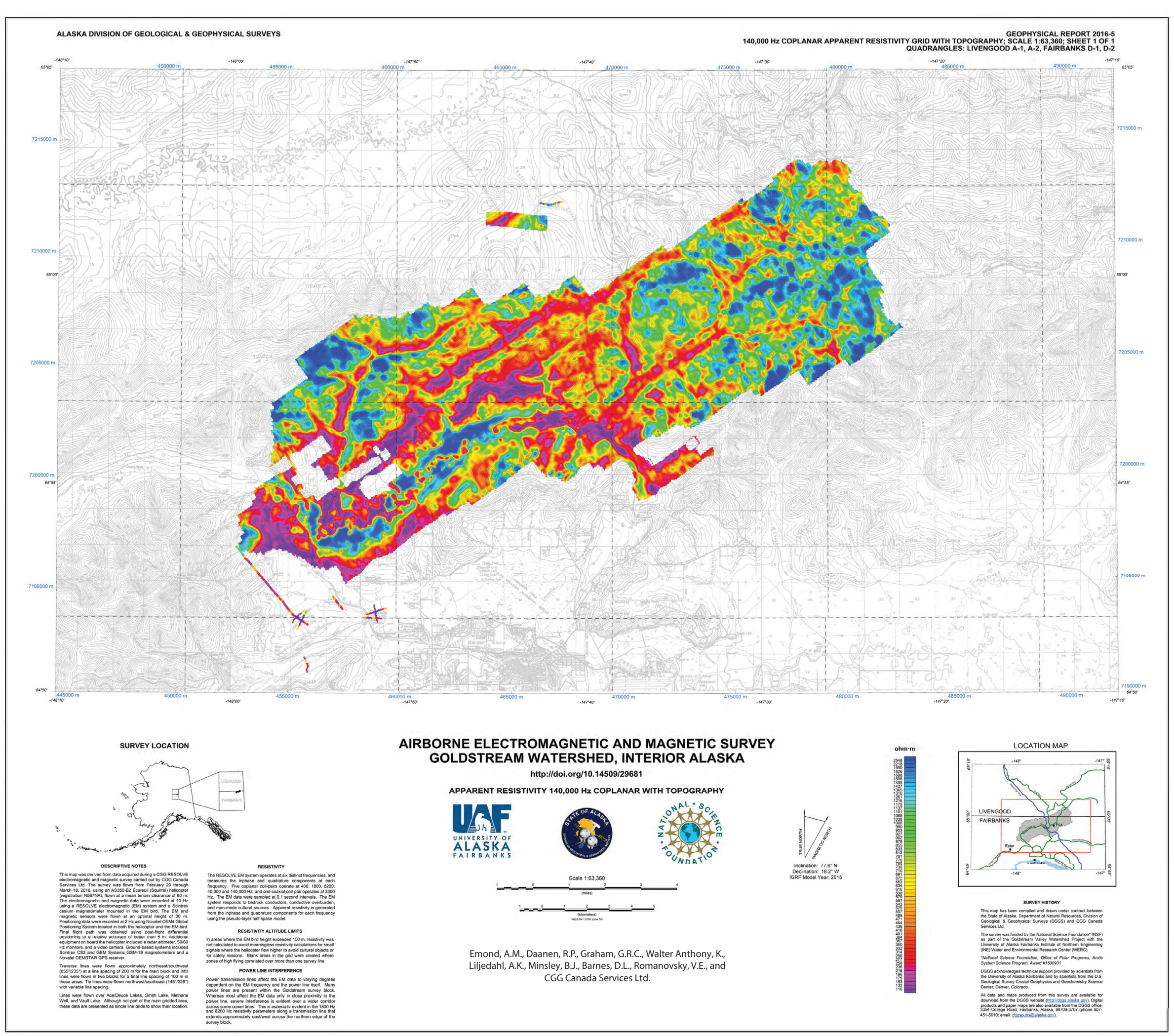




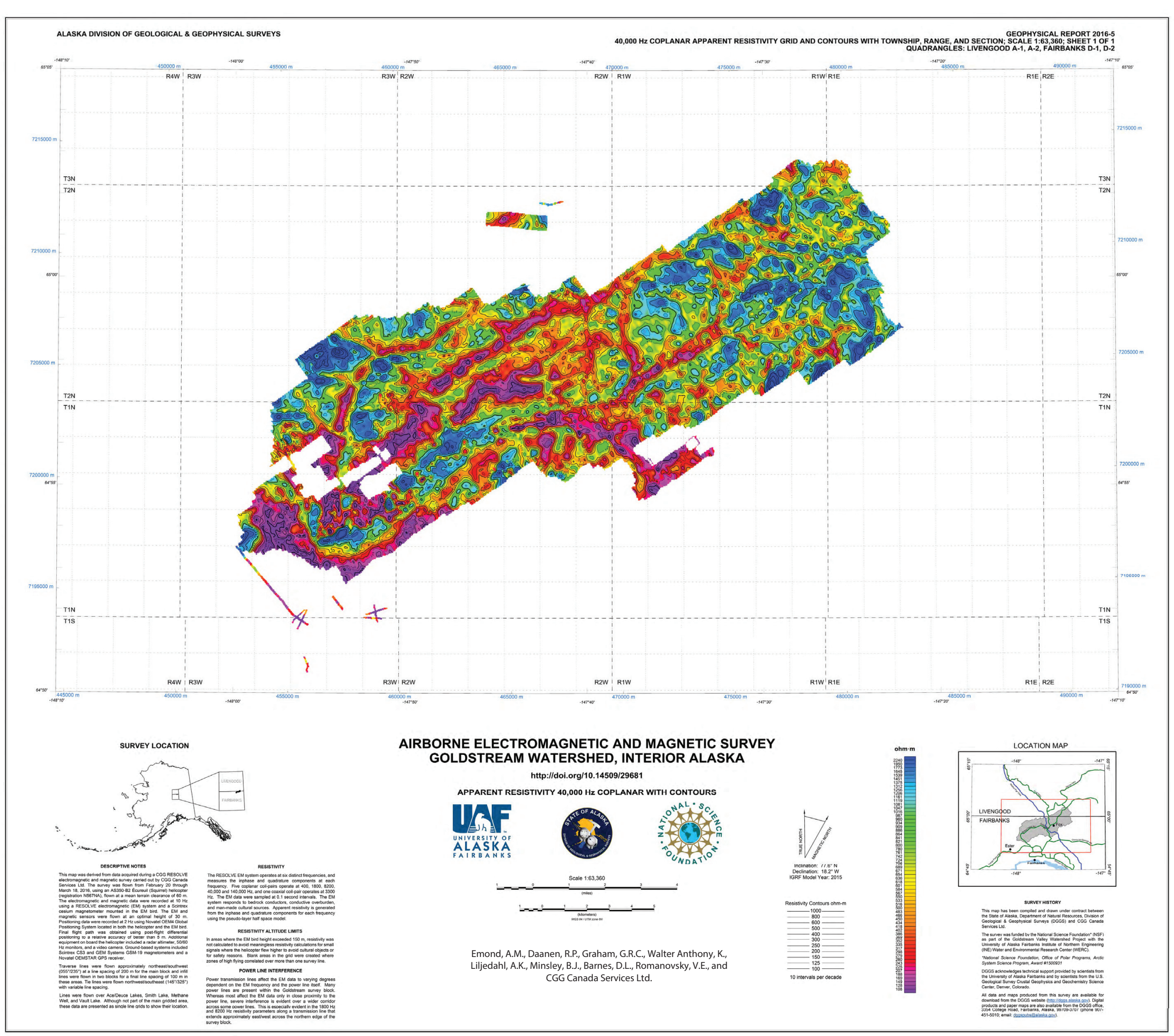




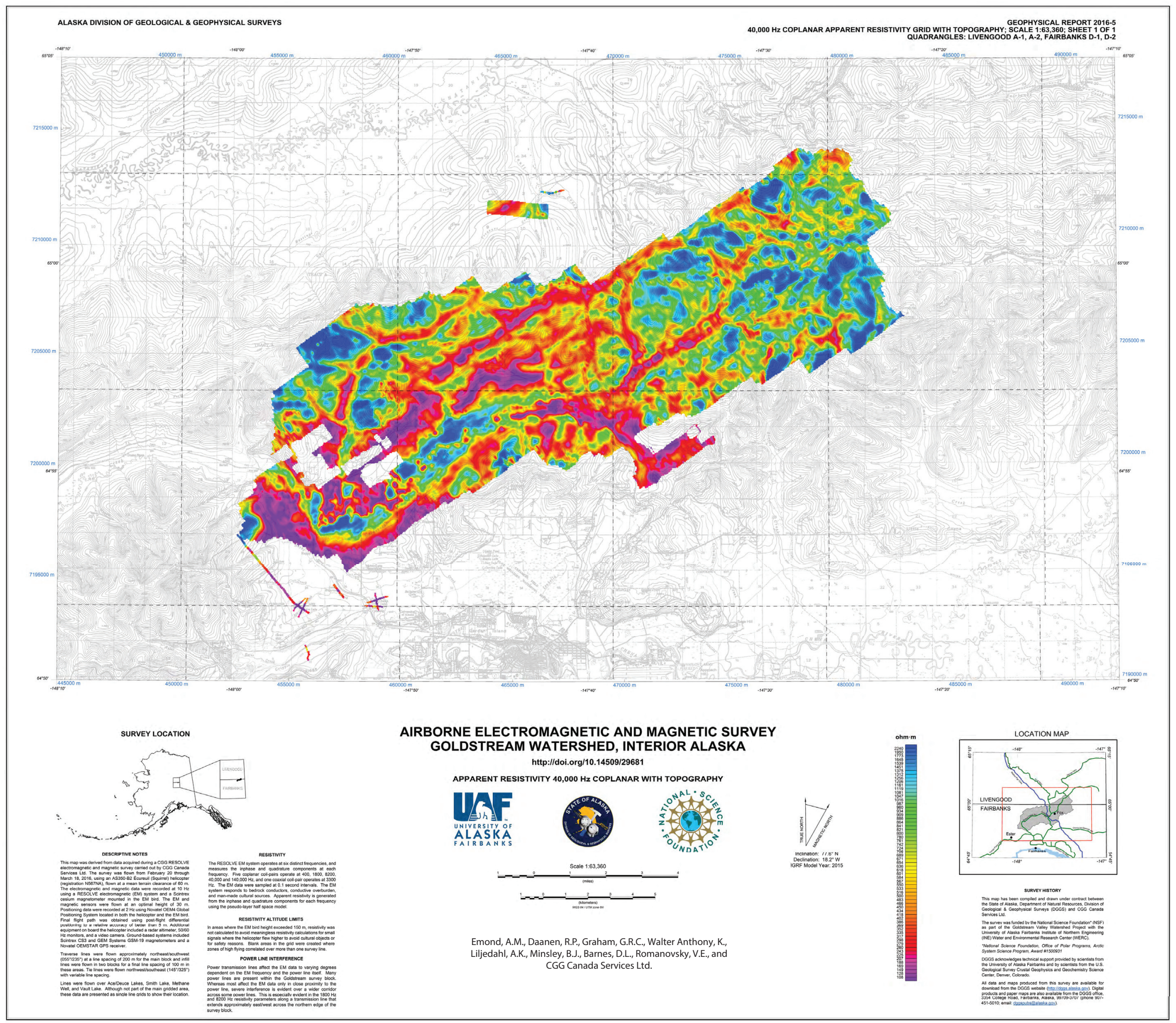




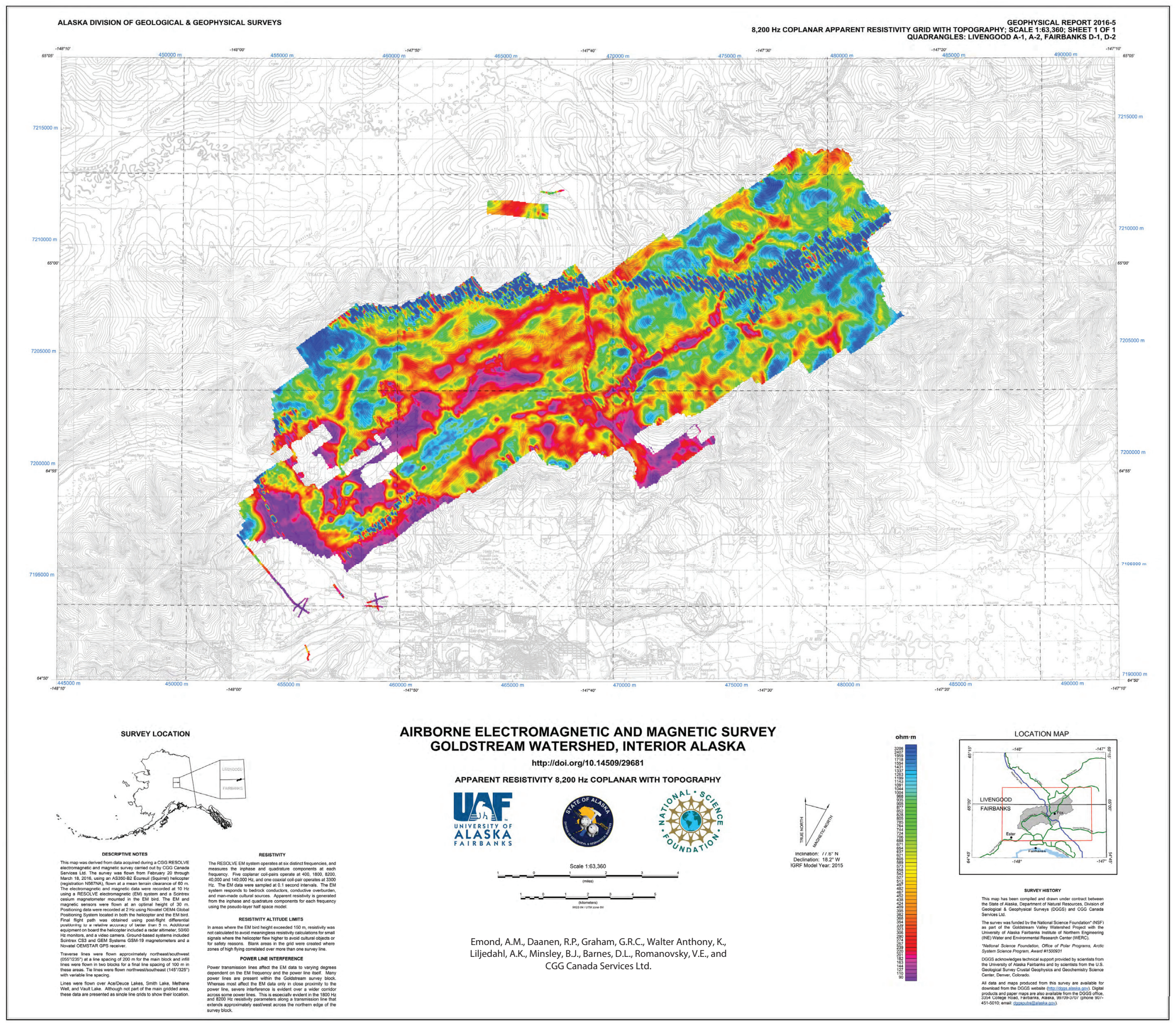




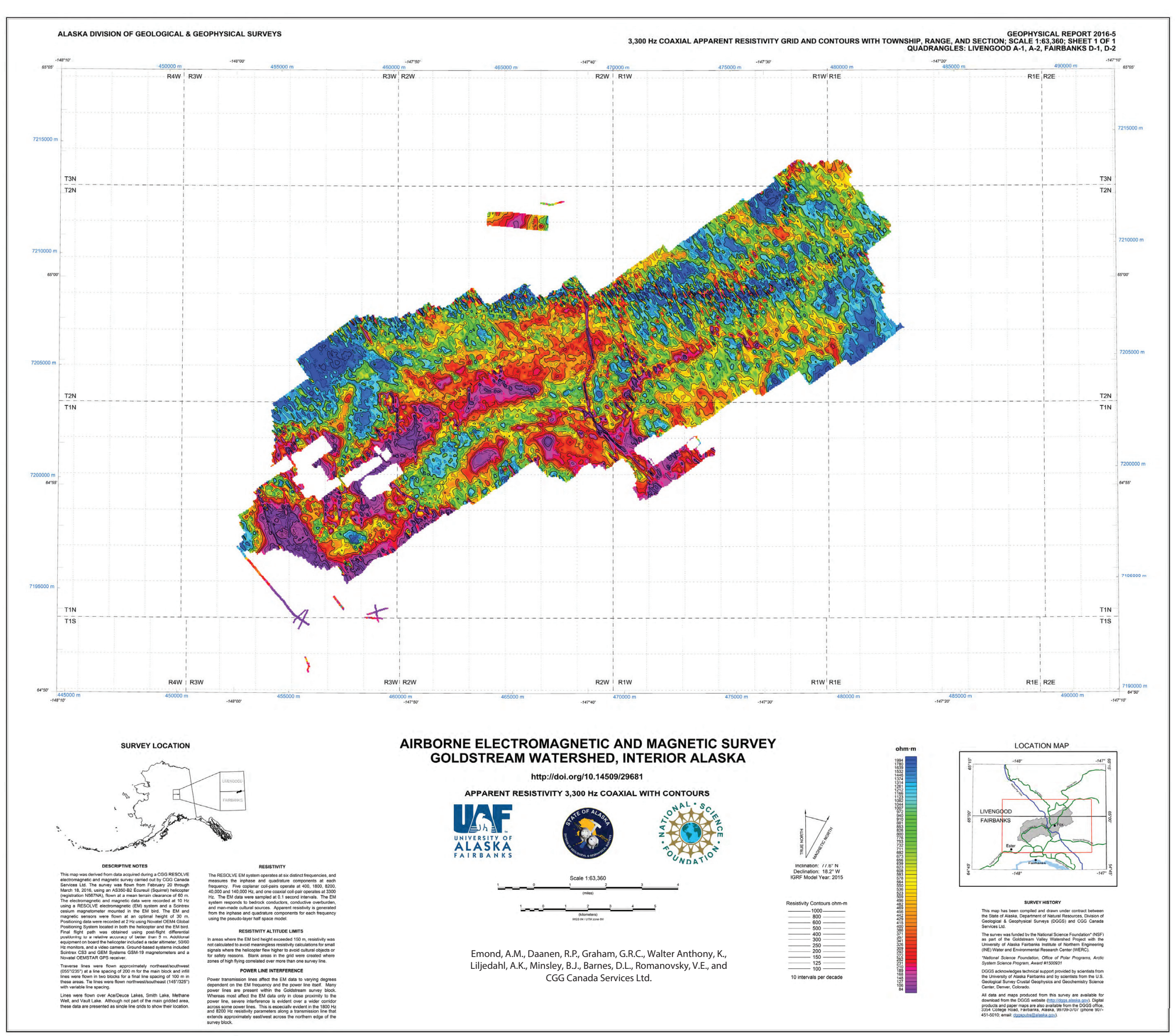




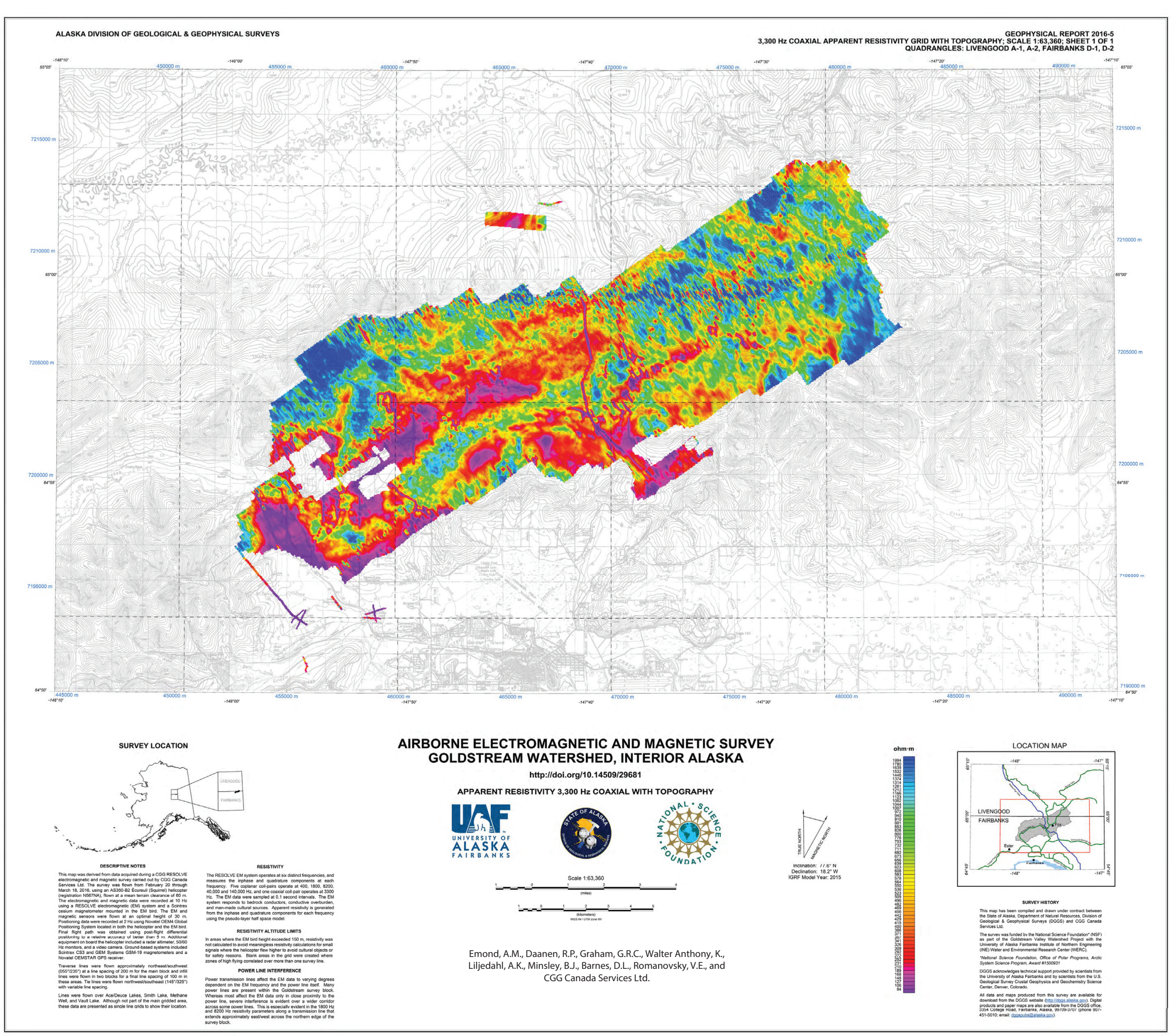




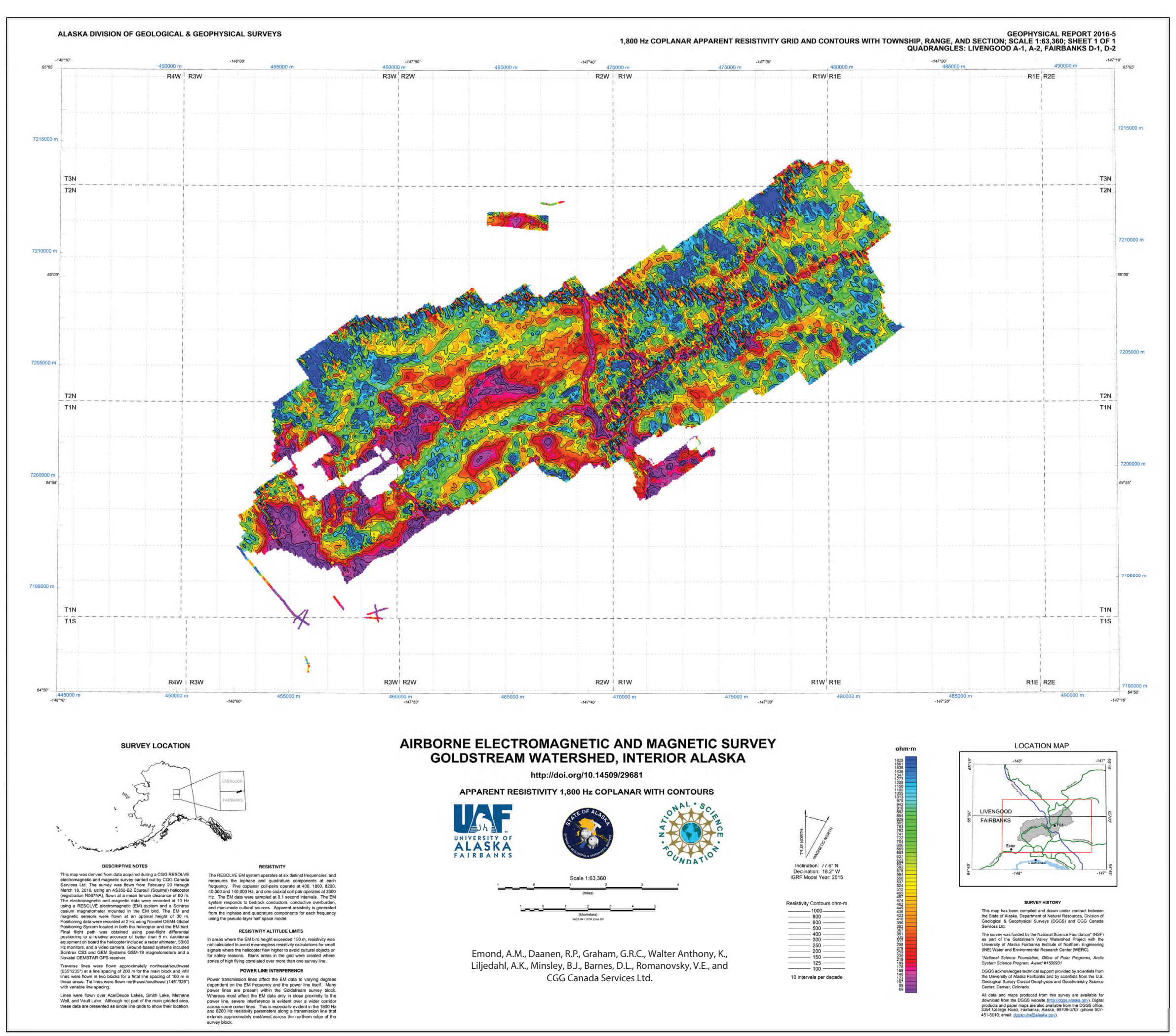




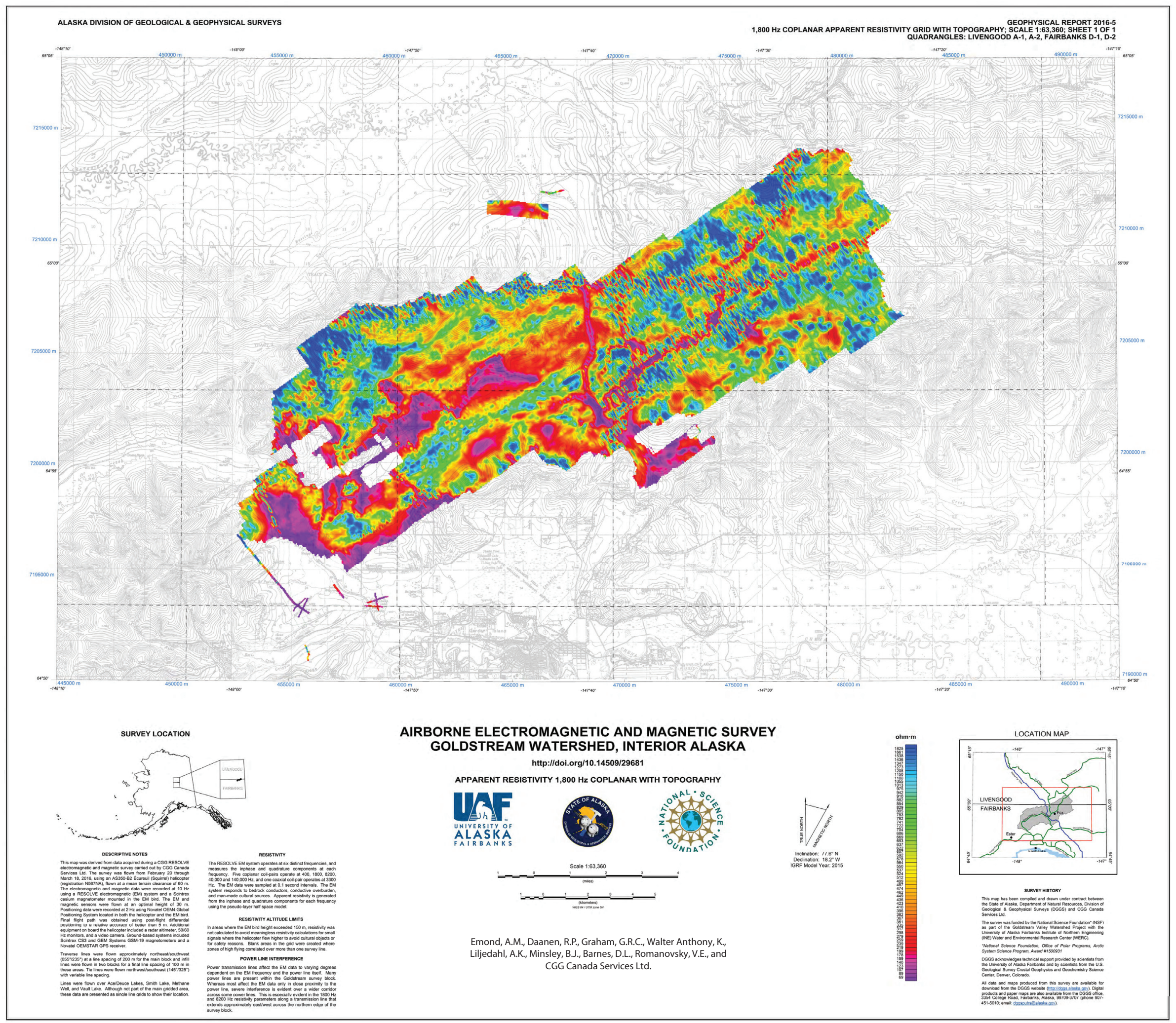




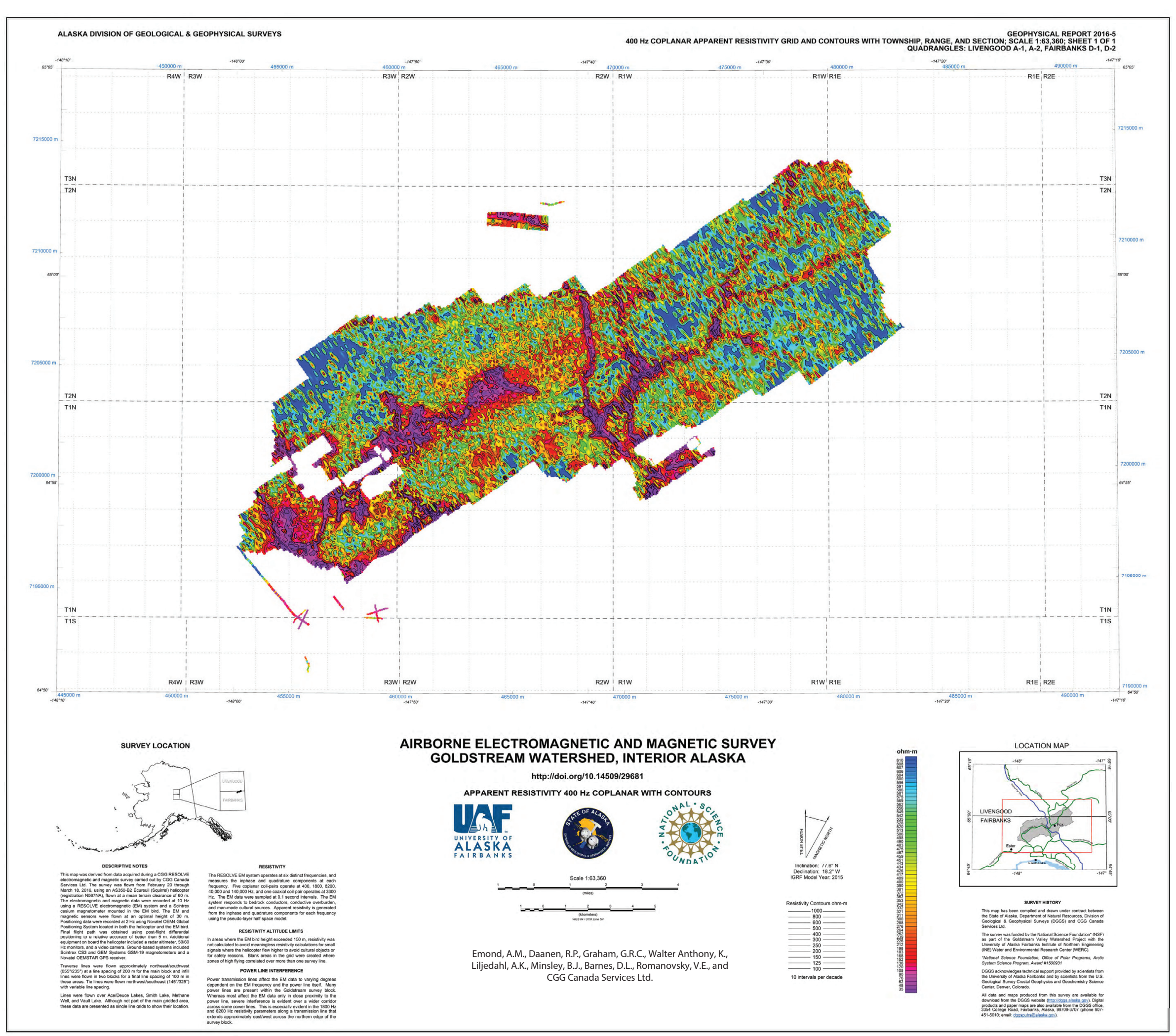




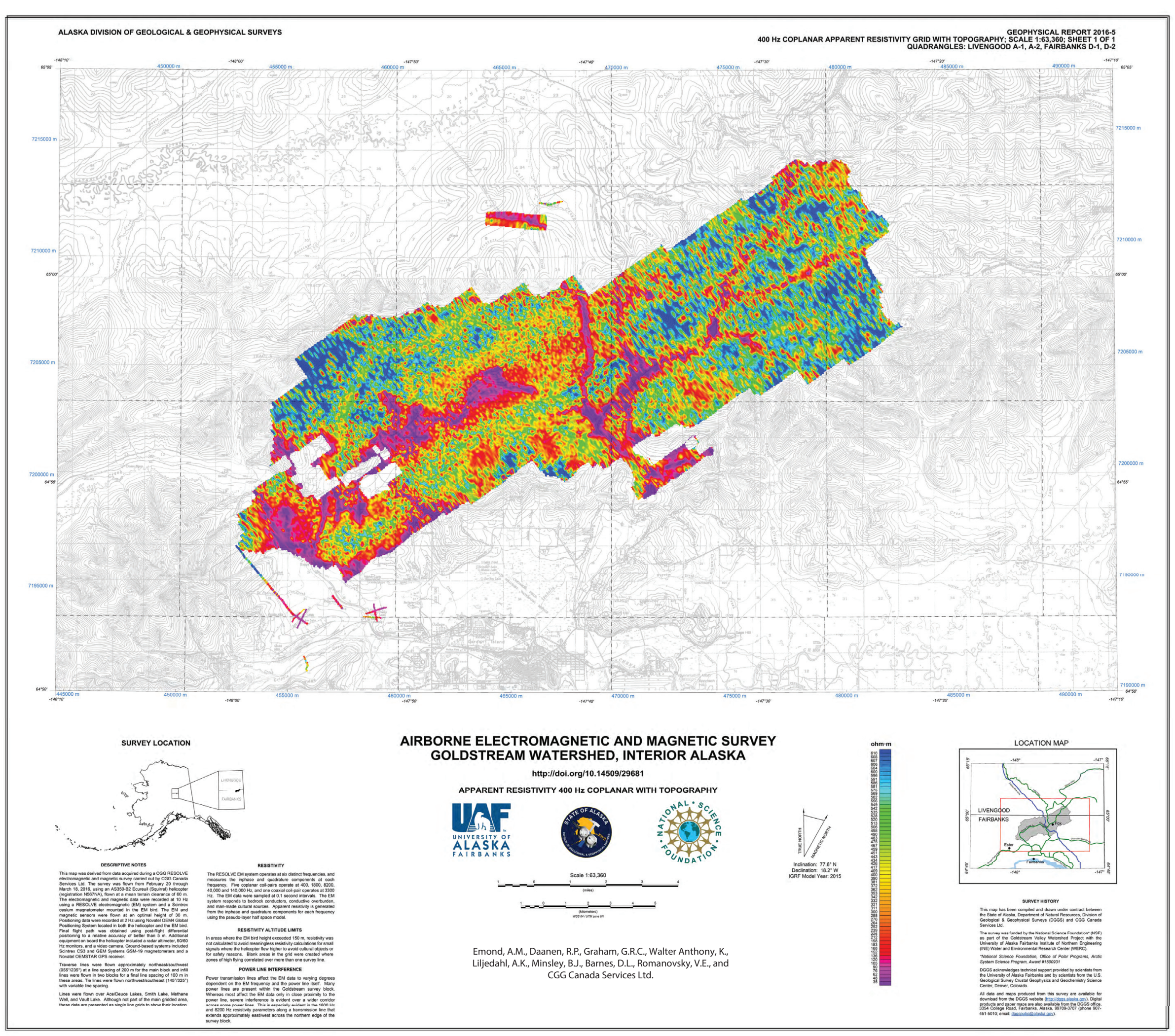




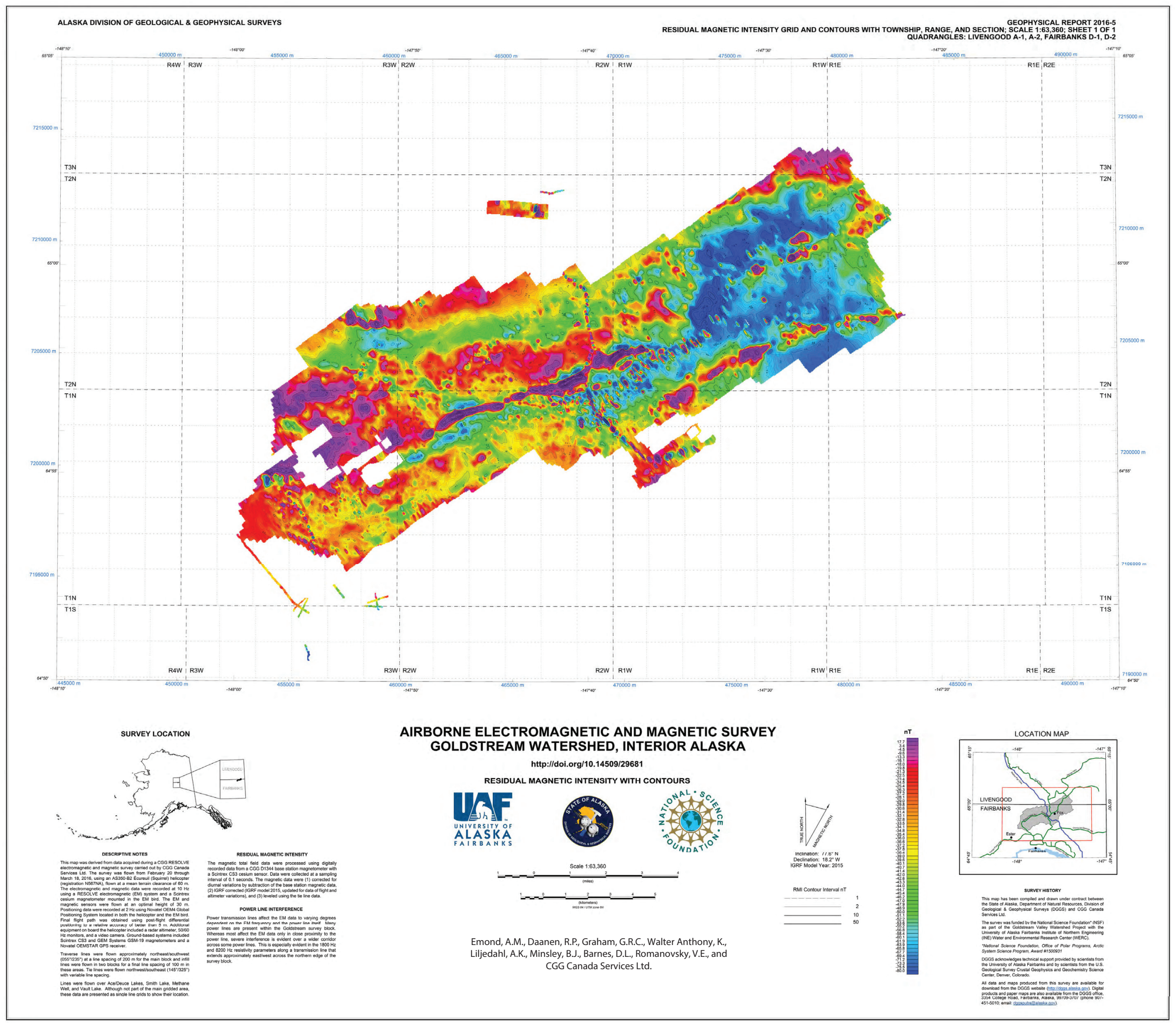




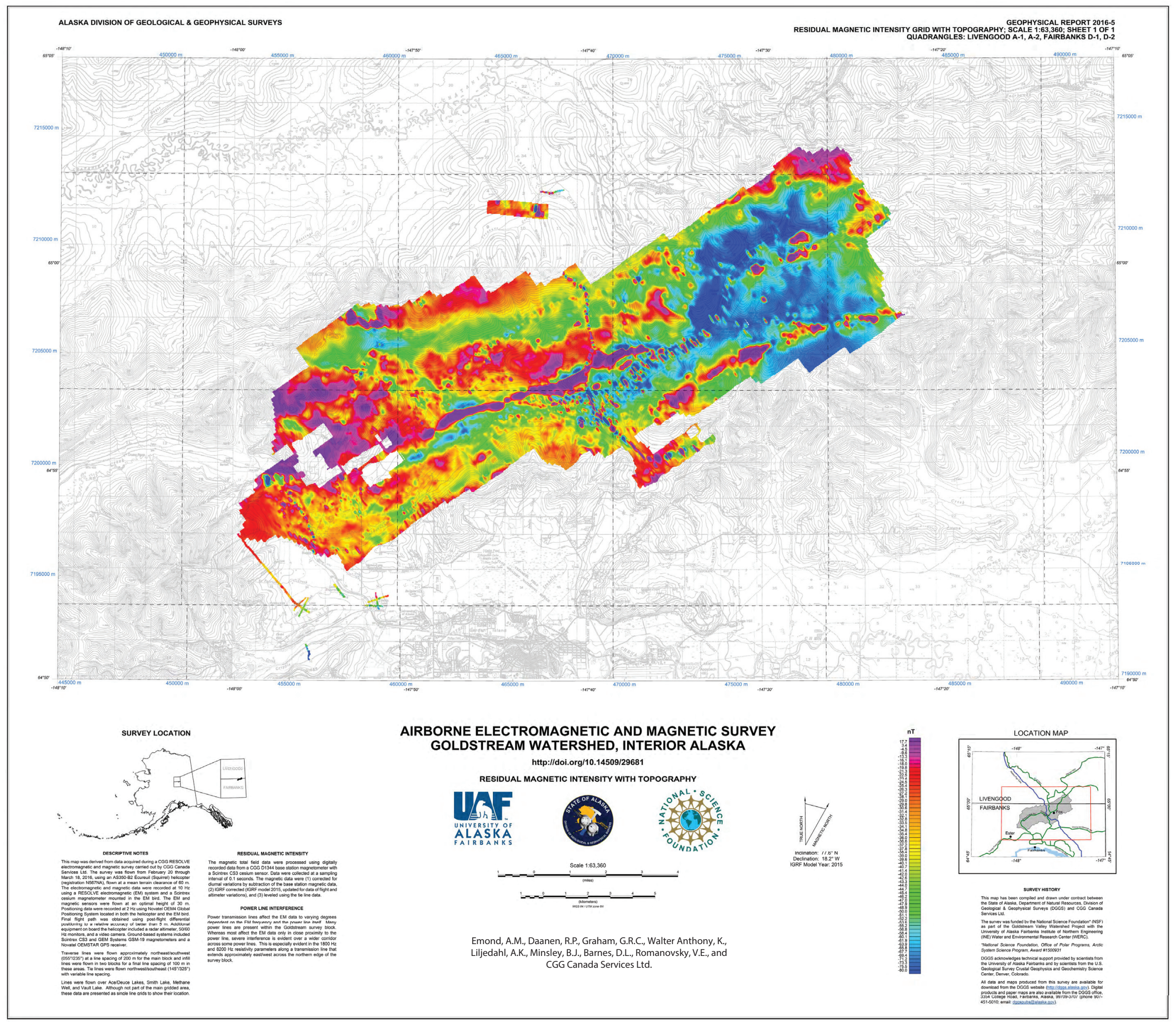

